\title{
Extending the Promise of Chimeric Antigen Receptor T-Cell Therapy Beyond Targeting CD19+ Tumors
}

Natalie S. Grover, $\mathrm{MD}^{1,2}$; Nicholas Tschernia, $\mathrm{MD}^{1,2}$; Gianpietro Dotti, $\mathrm{MD}^{1,3}$; and Barbara Savoldo, MD, $\mathrm{PhD}^{1,4}$

\section{INTRODUCTION}

Chimeric antigen receptor $T$ cells (CAR-Ts) targeted against CD19 have shown impressive activity in patients with B-cell leukemias and lymphomas. This has revolutionized the treatment landscape for patients with relapsed or refractory $(r / r)$ disease, providing hope for a possible curative approach for those who previously had limited available treatment options. ${ }^{1}$ The success of this approach has prompted interest in studying CAR-Ts for other hematologic malignancies and the development of CARs specific for other antigens. In this review, we discuss recent developments in CAR-Ts in multiple myeloma (MM), Hodgkin lymphoma (HL), T-cell malignancies, and acute myelogenous leukemia (AML; Fig 1).

\section{CHALLENGES BEYOND THE CD19 ANTIGEN}

CD19 is an excellent target for CAR-Ts given its almost universal expression in B-cell malignancies and tolerable on-target/off-tumor toxicity caused by the depletion of normal $\mathrm{B}$ lymphocytes that also express $\mathrm{CD}_{19 .}{ }^{2}$ In contrast, targeting lineage-restricted and nonlineage-restricted antigens in non-B-cell hematologic malignancies raises concerns about the manufacturing of CAR-T products and the clinical consequences associated with selecting antigens shared by normal cells. For example, in T-cell malignancies, targeting with CAR antigens that are lineage restricted and, thus, also expressed by healthy $T$ cells will inevitably cause the reciprocal elimination of $T$ cells, a phenomenon known as fratricide, preventing the generation, expansion, and persistence of CAR-Ts. ${ }^{3}$ Furthermore, infusion of CAR-Ts specific for T-cell-associated antigens in patients with T-cell malignancies, or myeloidassociated antigens in patients with AML, may seriously compromise host immunity because of prolonged T-cell depletion and myelosuppression, respectively. On the other hand, nonlineage-specific markers upregulated in malignant cells are inevitably characterized by heterogeneous expression within tumor cells, which can lead to tumor escape as a result of insufficient levels of antigen expression. With knowledge of these critical issues that move beyond CD19 targeting, we describe here some of the strategies implemented to overcome these challenges, such as gene editing techniques and conditional dual targeting.

\section{MM}

CAR-Ts that target CD19 (CD19.CAR-Ts) have been tested in a small number of patients with MM following the hypothesis that removing the B-cell precursor of plasma cells (PCs) could promote the eradication of differentiated PCs. While some responses were observed in patients with MM treated with CD19.CAR$\mathrm{Ts},{ }^{4,5}$ direct elimination of tumor PCs through targeting of PC-associated antigens seems a more viable option. To date, numerous antigens have been tested for eliminating malignant PCs. Prioritization was given to those with promising safety profiles (ie, high expression on tumor cells), with minimal expression on normal tissues.

B-cell maturation antigen. B-cell maturation antigen (BCMA) is a type 3 transmembrane protein commonly expressed on MM cells at varying receptor density. ${ }^{6}$ BCMA expression is restricted to late memory $B$ cells, plasmablasts, and differentiated $\mathrm{PCs}^{7,8}$ while being absent on nonhematologic tissues, hematopoietic stem cells (HSCs), naive B cells, and other hematopoietic lineages. ${ }^{9,10}$

CAR-Ts that target BCMA (BCMA.CAR) in MM have had the farthest progress to date. The first trial was piloted by the National Cancer Institute, which accrued 12 heavily pretreated patients with $\mathrm{r} / \mathrm{rMM} .^{11}$ The therapy showed a dose-dependent increase in both toxicity and efficacy: Patients enrolled at the highest dose $\left(9 \times 10^{6} \mathrm{CAR}-\mathrm{T}\right.$ cells/kg) developed severe, albeit reversible, cytokine release syndrome (CRS) and experienced clinical responses, including one complete response (CR) that lasted 17 weeks and a very good partial response (VGPR) that lasted 66 weeks. ${ }^{11}$ This early success jumpstarted many subsequent and ongoing clinical trials that targeted BCMA (Table 1; Appendix Table A1, online only).

A phase I study led by the University of Pennsylvania using a fully human BCMA.CAR enrolled 25 patients with $\mathrm{r} / \mathrm{rMM}$ treated in a dose escalation fashion with 


\section{CONTEXT}

\section{Key Objective}

What are the recent advances of chimeric antigen receptor T cells (CAR-Ts) that target antigens other than CD19 in hematologic malignancies?

\section{Knowledge Generated}

Challenges of developing CAR-Ts for non-B-cell malignancies include the selection of suitable antigens, limitation of ontarget/off-tumor toxicities, and complexity of the tumor microenvironment. We describe developments and future directions of CAR-T cells in multiple myeloma, Hodgkin lymphoma, T-cell malignancies, and acute myeloid leukemia.

\section{Relevance}

Novel CAR-Ts for hematologic malignancies are entering the clinic, proving that this strategy holds promise for other targets and supporting future work in solid tumors.

and without lymphodepletion. ${ }^{12}$ Twelve (48\%) of 25 patient achieved a partial response (PR) or better, including seven (64\%) of 11 patients who received lymphodepleting chemotherapy and the higher dose of BCMA.CAR-Ts ( $>10^{8}$ CAR-Ts $/ \mathrm{kg}$ ). Three of these participants had ongoing remissions that lasted $>11$ months, including one stringent $\mathrm{CR}(\mathrm{s} C \mathrm{C})$ that lasted 2.5 years. An important observation from this trial was the decreased BCMA expression on residual MM cells in patients who responded to BCMA.CAR-Ts. ${ }^{12} \mathrm{An}$ other phase I trial (bb2121) reported similar results in patients with $\mathrm{r} / \mathrm{rMM}$ : $85 \%$ objective response rate (ORR) with $45 \%$ either CR or sCR. ${ }^{13}$ Of note, responses occurred within a median time of 1 month after BCMA.CAR-T cell infusion with a trend for slower decreases in serum M-protein levels over up to 9 months. ${ }^{13}$

Other trials with BCMA.CAR-Ts have shown similar efficacy and toxicity profiles (Table 1; Appendix Table A1), including LCAR-B38M, ${ }^{14}$ MCARH171, ${ }^{15}$ JCARH125, ${ }^{16}$ and FCARH143. ${ }^{17}$ The latter study documented a patient who relapsed with low BCMA expression at day $79,{ }^{17}$ suggesting that antigen loss may be a mechanism of resistance, which supports a theme noted throughout different CAR-T therapies. Of note, while the great majority of clinical trials used viral vectors to manufacture BCMA.CAR-Ts, one phase I/II trial used a nonviral gene transfer approach, such as the transposon-based DNA modification system PiggyBac, to generate BCMA.CAR-Ts. ${ }^{18}$ Twenty-one patients with $\mathrm{r} / \mathrm{rMM}$ were enrolled, and $9.5 \%$ developed $\mathrm{CRS}$ grade $\leq 2$, with no grade $\geq 3$ events reported. The ORR was $100 \%$ in the higher dose cohort and $70 \%$ in the lower dose cohort. ${ }^{18} \mathrm{~A}$ phase II, open-label, efficacy and safety study is under way (ClinicalTrials.gov identifier: NCT03288493).

Although BCMA.CAR-Ts have generally demonstrated high response rates, the majority of patients ultimately experienced a relapse, stimulating interest in identifying mechanisms of resistance. While low BCMA expression plays a role in tumor escape, BCMA can also be cleaved from the cell membrane by $\gamma$-secretase. ${ }^{19} \mathrm{~A}$ clinical trial is currently ongoing that is testing whether combining BCMA.CAR-Ts with a smallmolecule $\gamma$-secretase inhibitor that blocks cleavage of BCMA can improve the efficacy of this therapy. ${ }^{20} \mathrm{Al}-$ ternatively, to limit tumor escape, the targeting of other antigens in combination with BCMA is being explored (Table 2).

CD138. CD138 (syndecan-1) is a member of the type 1 transmembrane heparan sulfate proteoglycans that acts as an extracellular matrix receptor and is highly expressed by terminally differentiated normal PCs and MM. Expression of CD138 on epithelial cells and endothelial cells presents a major concern for on-target/off-tumor toxicity after CD138-targeted therapy. ${ }^{21,22}$ Preclinical studies with CD138-redirected CAR-Ts (CD138.CAR-Ts) showed anti-MM activity both in vitro and in vivo, with no evidence of targeting epithelial and endothelial cells. ${ }^{23}$ A pilot phase I trial enrolled five patients with $r / r M M$ who received an average dose of $0.756 \times 10^{7} \mathrm{CD} 138$.CAR-Ts/ $/ \mathrm{kg}^{24}$ without lymphodepleting chemotherapy. Four patients achieved stable disease, which lasted between 3 and 7 months. The fifth patient had progressive disease despite the detection of CD138.CAR-Ts in the patient's bone marrow. A phase I dose escalation trial with CD138.CAR-Ts is under way at the University of North Carolina at Chapel Hill (UNC; ClinicalTrials.gov identifier: NCT03672318; Appendix Table A2, online only).

CD38. CD38, a glycoprotein with ectoenzymatic functions, represents an attractive target for CAR-T therapy because of its high expression on MM. ${ }^{25}$ However, CD38 is also expressed on normal nonmalignant cells of the hematopoietic system that include RBCs, natural killer (NK) cells, and T cells, among others, which poses safety concerns. To overcome this risk, 


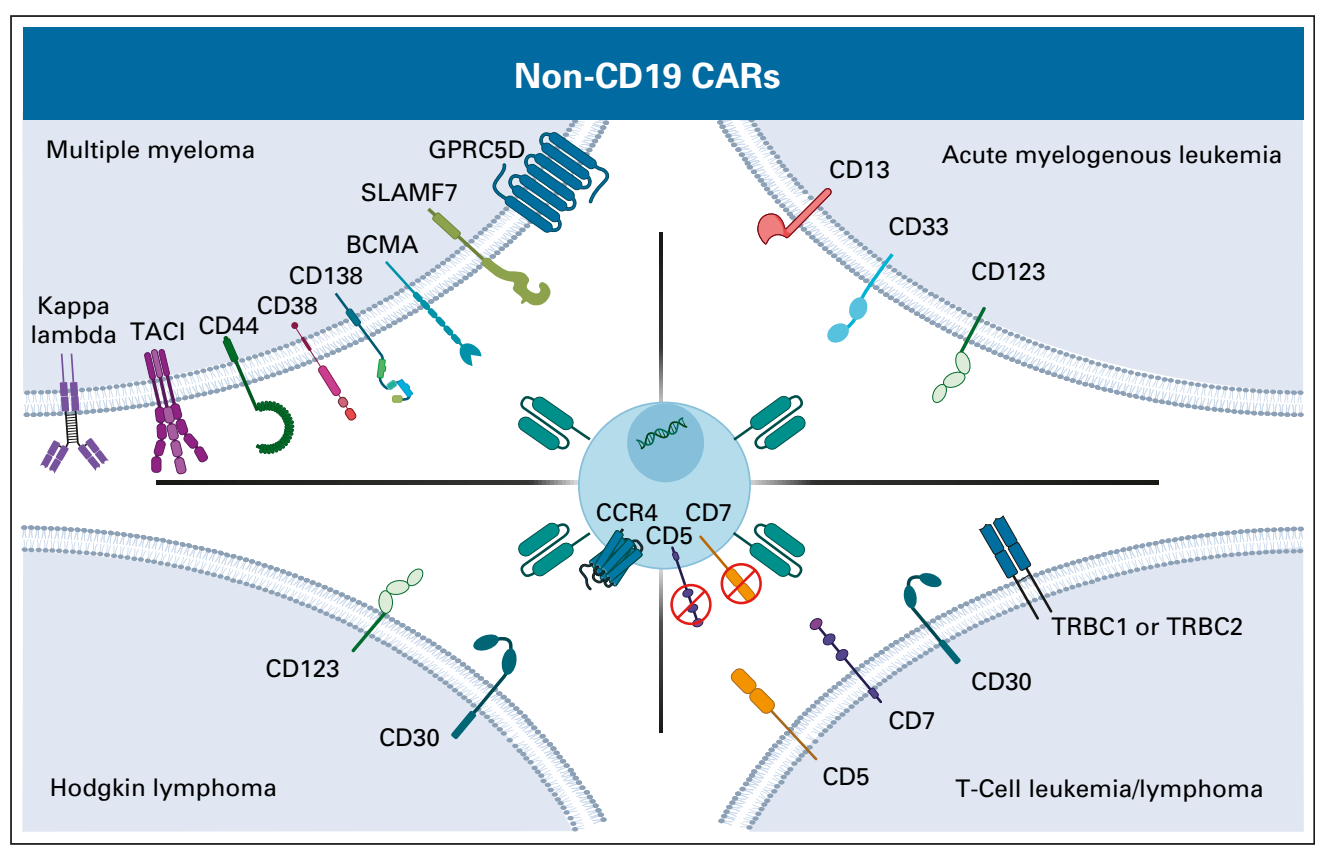

FIG 1. Composite diagram of leading targets for chimeric antigen receptor (CAR)-based therapy across multiple myeloma, acute myelogenous leukemia, Hodgkin lymphoma, and T-cell leukemia/lymphoma. Included in this diagram is the knockdown of CD5 and CD7 on transduced CAR T cells (CAR-Ts) by some active trials in an attempt to avoid CAR-T fratricide. Created with BioRender (BioRender, Toronto, Ontario, Canada). BCMA, B-cell maturation antigen; GPRC5D, G protein-coupled receptor class C group 5 member D; Kappa, $\kappa$-light chain; Lambda, $\lambda$-light chain; $\mathrm{TACl}$, transmembrane activator and CAML interactor.

preclinical studies explored single-chain variable fragments characterized by low affinity for CD38 aiming to generate CD38.CAR-Ts targeting preferentially MM cells characterized by higher CD38 density while sparing other cells. ${ }^{26,27} \mathrm{~A}$ phase I trial that is evaluating CD38.CAR-T safety and efficacy is under way (ClinicalTrials.gov identifier: NCT03464916; Appendix Table A2).

SLAMF7. SLAMF7 (signaling lymphocyte-activation molecule F7/CD319/CS1CRACC) is a member of the SLAM family of transmembrane receptors expressed by NK cells, B cells, T cells, dendritic cells, NK T cells, and monocytes. ${ }^{28,29}$ Relevant to this review, SLAMF7 is overexpressed in MM. A CAR targeting SLAMF7 (SLAMF7.CAR), derived from the humanized antiSLAMF7 antibody elotuzumab, was generated and showed activity against MM. ${ }^{30}$ Although SLAMF7 is also expressed by activated T cells, fratricide cytotoxic activity was largely restricted to those with high expression of SLAMF7, while lymphocytes with low expression were spared. More recently, a single-chain, bispecific CAR that targets both BCMA and SLAMF7 has been developed and has shown activity in vitro and in vivo in murine models. ${ }^{31}$ Preclinical evidence also suggests potential synergy between SLAMF7.CAR-Ts and the anti-MM agents lenalidomide and daratumumab. $^{32}$ There are at least four SLAMF7.CARs under clinical investigation (ClinicalTrials.gov identifiers: NCT03710421, NCT03958656, and NCT04142619; EudraCT identifier: 2019-001264-30; Table 2; Appendix Table A2). One of these studies (UCARTCS1) is testing a so-called off-the-shelf CAR. Briefly, allogeneic $T$ cells obtained from healthy donors are engineered to express the SLAMF7.CAR. These cells are also manipulated to have the expression of their inherent $\mathrm{T}$-cell receptor (TCR) and endogenous SLAMF7 disrupted, thereby preventing alloreactivity and fratricide effects, respectively.

Future directions. There has been substantial growth in the development of CAR-T therapies for MM over the years. In addition to known canonical antigens expressed in MM already targeted with monoclonal antibodies, other antigens are currently being investigated in MM, which include CD44 variant $6^{33,34}$ (ClinicalTrials.gov identifier: NCT04097301), G-protein-coupled receptor family class $\mathrm{C}$ group 5 member $\mathrm{D}, 35,36$ New York esophageal squamous cell carcinoma $1^{37}$ (ClinicalTrials.gov identifier: NCT03941626), NK group 2 member $D,{ }^{3840}$ CD56 $^{41,42}$ (ClinicalTrials.gov identifiers: NCT03473496 and NCT03271632), and integrin- $\beta 7^{43}$ (ClinicalTrials.gov identifier: NCT03778346; Table 2; Appendix Table A2). In the meantime, future studies should focus on identifying where BCMA.CAR-Ts fit in the current treatment paradigm for MM to maximize depth and 
TABLE 1. BCMA CAR-T Clinical Trials for Multiple Myeloma

\begin{tabular}{|c|c|c|c|c|c|c|c|c|c|c|c|}
\hline Trial & Phase & $\begin{array}{l}\text { No. of } \\
\text { Patients }\end{array}$ & $\begin{array}{l}\text { Median } \\
\text { Lines of Prior } \\
\text { Therapy }\end{array}$ & $\begin{array}{c}\text { CAR } \\
\text { Generation }\end{array}$ & $\begin{array}{l}\text { Costimulatory } \\
\text { Domain }\end{array}$ & Cell Dose & LD Regimen & Best Response & $\begin{array}{l}\text { Toxicity } \\
\text { (grade } \geq 3 \text { CRS/ } \\
\text { neurotoxicity) }\end{array}$ & Status & Study \\
\hline $\begin{array}{l}\text { Idecabtagene vicleucel } \\
\text { (bb2121, KarMMa) }\end{array}$ & $\|$ & $\begin{array}{c}128 \text { of } 140 \\
\text { enrolled }\end{array}$ & 6 & Second & $4-1 B B$ & $\begin{array}{l}150,300,450 \times 10^{6} \\
\text { CAR-Ts }\end{array}$ & $\begin{array}{l}3 \text { doses of } 300 \mathrm{mg} / \mathrm{m}^{2} \\
\text { Cy and of } 30 \mathrm{mg} / \mathrm{m}^{2} \\
\text { fludarabine }\end{array}$ & $\begin{array}{l}\text { ORR, } 73 \% \\
42 \text { patients } \\
\text { (33\%) in CR/ } \\
\text { sCR }\end{array}$ & $\begin{array}{l}\text { Grade } \geq 3 \text { CRS, } 7 \text { (5\%; one } \\
\text { grade } 5 \text { event) } \\
\text { Grade } \geq 3 \text { neurotoxicity, } \\
4(3 \%)\end{array}$ & Ongoing & $\begin{array}{l}\text { ClinicalTrials.gov identifier: } \\
\text { NCT03361748 }\end{array}$ \\
\hline $\begin{array}{l}\text { LCAR-B38M } \\
\text { (LEGEND-2) }\end{array}$ & $|/| \mid$ & $\begin{array}{l}57 \text { (of } 100 \\
\text { planned) }\end{array}$ & 3 & Second & $4-1 B B$ & $\begin{array}{c}0.5 \times 10^{6} \mathrm{cells} / \mathrm{kg} \\
\text { median CAR-Ts }\end{array}$ & $\begin{array}{l}3 \text { doses of } 300 \mathrm{mg} / \mathrm{m}^{2} \\
\text { Cy }\end{array}$ & $\begin{array}{l}\text { ORR, 88\% } \\
39 \text { in CR (68\%) } \\
3 \text { in VGPR } \\
(5 \%) \\
8 \text { in PR (14\%) } \\
\text { mPFS, } \\
15 \text { months }\end{array}$ & $\begin{array}{l}\text { Grade } \geq 3 \text { CRS, } 4 \text { (7\%) } \\
\text { Grade } \geq 3 \text { neurotoxicity, } \\
0\end{array}$ & Ongoing & $\begin{array}{l}\text { ClinicalTrials.gov identifier: } \\
\text { NCT03090659 }\end{array}$ \\
\hline LCAR-B38M ${ }^{a}$ & $|/| \mid$ & 17 & 4 & Second & $4-1 B B$ & $\begin{array}{l}0.21-1.52 \times 10^{6} \\
\text { CAR-Ts/kg }\end{array}$ & Cy and fludarabine & $\begin{array}{l}\text { ORR, } 88.2 \%(15 \\
\text { of } 17) \\
13 \text { in SCR } \\
2 \text { in VGPR }\end{array}$ & $\begin{array}{l}\text { Grade } \geq 3 \text { CRS, } 6 \text { ( } 1 \text { grade } 5 \\
\text { event from a very severe } \\
\text { toxic reaction) } \\
\text { Grade } \geq 3 \text { neurotoxicity, } \\
0\end{array}$ & Ongoing & ChiCTR-ONH-17012285 \\
\hline $\begin{array}{l}\text { JNJ-4528 } \\
\text { (CARTITUDE-1) }\end{array}$ & $\mid / / 1$ & $\begin{array}{l}29 \text { (of } \\
\text { planned } \\
118 \text { ) }\end{array}$ & 5 & Second & $4-1 B B$ & $\begin{array}{l}\text { Target dose: } 0.75 \times 10^{6} \\
\text { viable CAR-Ts/kg } \\
\text { Median administered: } \\
0.73 \times 10^{6} \text { viable } \\
\text { CAR-Ts } / \mathrm{kg}\end{array}$ & $\begin{array}{l}\text { Cy } 300 \mathrm{mg} / \mathrm{m}^{2}+ \\
\text { fludarabine } 30 \mathrm{mg} / \mathrm{m}^{2} \\
\text { over } 3 \text { days used for } \\
\text { LD }\end{array}$ & $\begin{array}{l}\text { ORR, } 100 \% \\
22 \text { in SCR } \\
(76 \%) \\
6 \text { in VGPR } \\
(21 \%) \\
1 \text { in PR (3\%) }\end{array}$ & $\begin{array}{l}\text { Grade } \geq 3 \text { CRS, } 2 \text { (7\%; one } \\
\text { grade } 5 \text { event) } \\
\text { Grade } \geq 3 \text { neurotoxicity, } \\
1(3 \%)\end{array}$ & Ongoing & $\begin{array}{l}\text { ClinicalTrials.gov identifier: } \\
\text { NCT03548207 }\end{array}$ \\
\hline $\begin{array}{l}\text { JCARH125 (orva-cel, } \\
\text { first two dose levels } \\
\text { of EVOLVE) }\end{array}$ & $1 / 11$ & 44 & 7 & Second & $4-1 B B$ & $50,150 \times 10^{6} \mathrm{CAR}-\mathrm{Ts}$ & $\begin{array}{l}3 \text { doses of } 300 \mathrm{mg} / \mathrm{m}^{2} \\
\text { Cy and of } 30 \mathrm{mg} / \mathrm{m}^{2} \\
\text { fludarabine }\end{array}$ & $\begin{array}{l}\text { ORR, } 82 \% \text { across } \\
\text { all dose levels } \\
48 \% \text { in VGPR } \\
27 \% \text { in PR }\end{array}$ & $\begin{array}{l}\text { Grade } \geq 3 \text { CRS, 9\% } \\
\text { Grade } \geq 3 \text { neurotoxicity } \\
7 \%\end{array}$ & Ongoing & $\begin{array}{l}\text { ClinicalTrials.gov identifier: } \\
\text { NCT03430011 }\end{array}$ \\
\hline $\begin{array}{l}\text { JCARH125 (orva-cel } \\
\text { dose escalation of } \\
\text { EVOLVE) }\end{array}$ & $|/| \mid$ & 62 & 6 & Second & $4-1 B B$ & $\begin{array}{l}300,450,600 \times 10^{6} \\
\text { CAR-Ts }\end{array}$ & $\begin{array}{l}3 \text { doses of } 300 \mathrm{mg} / \mathrm{m}^{2} \\
\text { Cy and of } 30 \mathrm{mg} / \mathrm{m}^{2} \\
\text { fludarabine }\end{array}$ & $\begin{array}{l}\text { ORR, 92\% } \\
36 \% \text { in CR/ } \\
\text { sCR } \\
32 \% \text { in VGPR } \\
24 \% \text { in PR }\end{array}$ & $\begin{array}{l}\text { Grade } \geq 3 \text { CRS, } 2 \text { (3\%) } \\
\text { Grade } \geq 3 \text { neurotoxicity, } \\
2(3 \%)\end{array}$ & Ongoing & $\begin{array}{l}\text { ClinicalTrials.gov identifier: } \\
\text { NCT03430011 }\end{array}$ \\
\hline PiggyBac & $|/| \mid$ & 21 & 6 & Second & $4-1 B B$ & $\begin{array}{l}48-430 \times 10^{6} \text { P-BCMA- } \\
101 \text { CAR-Ts }\end{array}$ & $\begin{array}{l}3 \text { doses of } 300 \mathrm{mg} / \mathrm{m}^{2} \\
\text { Cy and of } 30 \mathrm{mg} / \mathrm{m}^{2} \\
\text { fludarabine }\end{array}$ & $\begin{array}{l}\text { ORR (6 treated } \\
\text { above cohort } \\
1 \text { dose), } 83 \% \\
1 \text { in sCR } \\
1 \text { in VGPR } \\
3 \text { in PR }\end{array}$ & $\begin{array}{l}\text { Grade } \geq 3 \text { CRS, } 0 \\
\text { Grade } \geq 3 \text { neurotoxicity, } \\
0\end{array}$ & Ongoing & $\begin{array}{l}\text { ClinicalTrials.gov identifier: } \\
\text { NCT03288493 }\end{array}$ \\
\hline $\begin{array}{l}\text { SZ-CART-MM02 (dual } \\
\text { CD19/BCMA CAR) }\end{array}$ & $|/|||$ & $\begin{array}{l}10 \text { of } 15 \\
\text { planned }\end{array}$ & & $\begin{array}{l}\text { Third } \\
\text { (BCMA } \\
\text { CAR) }\end{array}$ & $\mathrm{CD} 28 / 0 \times 40$ & $\begin{array}{l}2-6 \times 10^{7} \mathrm{BCMA}^{+} \\
\text {CAR-Ts } / \mathrm{kg}\end{array}$ & $\begin{array}{l}\text { Tandem auto-HSCT } \\
\text { (busulfan and Cy } \\
\text { conditioning) }\end{array}$ & $\begin{array}{l}\text { ORR, } 100 \% \text { (10 } \\
\text { of } 10 \text { ) } \\
80 \% \text { in CR/ } \\
\text { sCR } \\
20 \% \text { in VGPR }\end{array}$ & $\begin{array}{l}\text { Grade } \geq 3 \text { CRS, } 0 \\
\text { Grade } \geq 3 \text { neurotoxicity, } \\
0\end{array}$ & Ongoing & $\begin{array}{l}\text { ClinicalTrials.gov identifier: } \\
\text { NCT03455972 (dual } \\
\text { CD19/BCMA) }\end{array}$ \\
\hline
\end{tabular}

Abbreviations: auto-HSCT, autologous hematopoietic stem-cell transplantation; BCMA, B-cell maturation antigen; CAR, chimeric antigen receptor; CAR-T, chimeric antigen receptor T cell; ChiCTR,

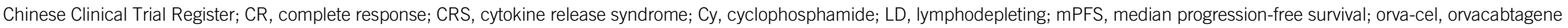
autoleucel; ORR, objective response rate; PR, partial response; SCR, stringent complete response; VGPR, very good partial response.

${ }^{a}$ single-chain variable fragments (scFvs) are directed against two distinct BCMA epitopes (VH1 and VH2) 
TABLE 2. Non-BCMA CAR-T Clinical Trials for Multiple Myeloma

\begin{tabular}{|c|c|c|c|c|c|c|c|c|c|c|c|}
\hline Target and Trial & Phase & $\begin{array}{l}\text { No. of } \\
\text { Patients }\end{array}$ & $\begin{array}{l}\text { Median } \\
\text { Lines of } \\
\text { Prior } \\
\text { Therapy }\end{array}$ & $\begin{array}{c}\text { CAR } \\
\text { Generation }\end{array}$ & $\begin{array}{l}\text { Costimulatory } \\
\text { Domain }\end{array}$ & Cell Dose & LD Regimen & Best Response & $\begin{array}{c}\text { Toxicity } \\
\text { (grade } \geq 3 \text { CRS/ } \\
\text { neurotoxicity) }\end{array}$ & Status & Study \\
\hline \multicolumn{12}{|l|}{ CD38/BCMA } \\
\hline $\begin{array}{l}\text { Dual-specificity CD38 } \\
\text { and BCMA }\end{array}$ & $|/| I$ & 80 & $\geq 1$ & NA & NA & $\begin{array}{l}1-5 \times 10^{6} \\
\text { CAR-Ts } / \mathrm{kg}\end{array}$ & NA & Ongoing & Ongoing & Ongoing & $\begin{array}{l}\text { ClinicalTrials.gov } \\
\text { identifier: } \\
\text { NCT03767751 }\end{array}$ \\
\hline \multicolumn{12}{|l|}{ CD138 } \\
\hline CART-138 & $|/|||$ & $\begin{array}{l}5 \text { of } 10 \\
\text { planned } \\
\text { reported }\end{array}$ & 11 & Second & $4-1 B B$ & $\begin{array}{l}\text { Average of } 0.756 \\
\times 10^{7} \text { cytokine- } \\
\text { induced killer } \\
\text { cells } / \mathrm{kg}\end{array}$ & $\begin{array}{l}3 \text { received Cy } \\
1 \text { received PCD } \\
1 \text { received VAD }\end{array}$ & $\begin{array}{l}4 \mathrm{SD} \\
1 \mathrm{PD}\end{array}$ & $\begin{array}{l}\text { Grade } \geq 3 \text { CRS, 4/ } \\
5 \text { (fever) } \\
\text { Grade } \geq 3 \\
\text { neurotoxicity, } 0\end{array}$ & Stopped & $\begin{array}{l}\text { ClinicalTrials.gov } \\
\text { identifier: } \\
\text { NCT01886976 }\end{array}$ \\
\hline \multicolumn{12}{|l|}{$\begin{array}{c}\text { CD138/BCMA/ } \\
\text { CD19 }\end{array}$} \\
\hline CART-138/BCMA/19 & $|/| \mid$ & 10 & $\geq 1$ & NA & NA & $\begin{array}{r}5-100 \times 10^{6} \\
\text { CAR-Ts } / \mathrm{kg}\end{array}$ & $\begin{array}{l}3 \text { doses of } 300 \mathrm{mg} / \\
\mathrm{m}^{2} \mathrm{Cy} \text { and of } \\
30 \mathrm{mg} / \mathrm{m}^{2} \\
\text { fludarabine }\end{array}$ & Ongoing & Ongoing & Ongoing & $\begin{array}{l}\text { ClinicalTrials.gov } \\
\text { identifier: } \\
\text { NCT03196414 }\end{array}$ \\
\hline \multicolumn{12}{|l|}{$\mathrm{BCMA} / \mathrm{TACl}$} \\
\hline AUTO2 & $|/|||$ & 12 & $\geq 3$ & Third & CD20/0X40 & $\begin{array}{l}15 \times 10^{6} \text { to } 350 \times \\
10^{6} \text { APRIL } \\
\text { CAR-Ts }\end{array}$ & Cy and fludarabine & $\begin{array}{l}\text { Terminated after } \\
\text { interim analysis } \\
\text { showed lack of } \\
\text { efficacy }\end{array}$ & Terminated & Terminated & $\begin{array}{l}\text { ClinicalTrials.gov } \\
\text { identifier: } \\
\text { NCT03287804 }\end{array}$ \\
\hline \multicolumn{12}{|l|}{ SLAMF7/CS1 } \\
\hline CARAMBA-1 & I/lla & 38 & $\geq 2$ & Second & CD28 & NA & NA & Ongoing & Ongoing & Ongoing & $\begin{array}{c}\text { EudraCT 2019- } \\
\text { 001264-30 }\end{array}$ \\
\hline \multicolumn{12}{|l|}{ CD44v6 } \\
\hline MLM-CAR44.1 T-cells & $|/| \mid$ & 58 & $\geq 4$ & NA & NA & $\begin{array}{c}0.5,1,2 \times 10^{6} \\
\text { CAR-Ts } / \mathrm{kg}\end{array}$ & Cy and fludarabine & Ongoing & Ongoing & Ongoing & $\begin{array}{l}\text { ClinicalTrials.gov } \\
\text { identifier: } \\
\text { NCT04097301 }\end{array}$ \\
\hline \multicolumn{12}{|l|}{$\begin{array}{l}\text { CD38/BCMA/ } \\
\text { NY-ESO-1 }\end{array}$} \\
\hline Multitargeted CARs & $|/|||$ & 73 & NA & NA & NA & NA & Cy and fludarabine & Ongoing & Ongoing & Ongoing & $\begin{array}{l}\text { ClinicalTrials.gov } \\
\text { identifier: } \\
\text { NCT03638206 }\end{array}$ \\
\hline \multicolumn{12}{|l|}{$\begin{array}{l}\text { CD56/CD38/ } \\
\text { CD138/BCMA }\end{array}$} \\
\hline Multitargeted CARs & $|/|||$ & 20 & $\geq 4$ & NA & NA & NA & NA & Ongoing & Ongoing & Ongoing & $\begin{array}{l}\text { ClinicalTrials.gov } \\
\text { identifier: } \\
\text { NCT03271632 }\end{array}$ \\
\hline
\end{tabular}

Abbreviations: BCMA, B-cell maturation antigen; CAR, chimeric antigen receptor; CAR-T, chimeric antigen receptor T cell; CRS, cytokine release syndrome; Cy, cyclophosphamide; LD, Iymphodepleting; PCD, pomalidomide, cyclophosphamide, and dexamethasone; NA, not available in published literature or in trial registry; PD, progressive disease; SD, stable disease; VAD, vincristine, doxorubicin, and 
duration of clinical responses. Furthermore, combinations of BCMA.CAR-Ts with other immunomodulatory agents and the development of bispecific CAR-Ts are warranted to prevent tumor escape. Finally, the tumor microenvironment (TME) of MM likely plays a role in impairing CAR-T function, and countering inhibitory mechanisms should enhance the therapeutic index of CAR-Ts in MM.

\section{HL}

CD19. CAR-Ts have been explored in HL with the goal of eradicating the putative CD19-expressing Hodgkin ReedSternberg (HRS) clonotypic cells and B cells within the TME. ${ }^{44,45}$ Four patients infused with CD19.CAR-Ts obtained through mRNA electroporation did not experience toxicity, but responses were limited and transient at best. ${ }^{46}$ Thus, alternative targets must be considered for $\mathrm{HL}$.

CD30, a member of the tumor necrosis factor receptor superfamily, ${ }^{47}$ is the most attractive target for $\mathrm{HL}$, being expressed on virtually all HRS cells. ${ }^{48} \mathrm{CD} 30$ is only found on a small subset of activated T and B cells, so it has a low risk for fratricide and potential toxicity. ${ }^{49}$ The feasibility of targeting $\mathrm{CD} 30$ in $\mathrm{HL}$ has been demonstrated by the success and favorable safety profile of brentuximab vedotin, an antibody drug conjugate directed against $\mathrm{CD} 30,{ }^{50}$ stimulating the development of CD30-specific CAR-Ts (CD30.CARTs; Table 3; Appendix Table A3, online only).

In the first published trial of CD30.CAR-Ts conducted in China, 17 patients with HL were treated, and six achieved PR, but none achieved a CR. ${ }^{51}$ Toxicities were minimal, with no CRS observed. Although CAR transgene levels decreased to baseline 4-8 weeks after infusion, there were higher numbers of CD30.CAR-Ts in post-treatment biopsies as well as a decreased number of $\mathrm{CD}^{+} 0^{+}$tumor cells, suggesting that even with undetectable levels in peripheral blood, CD30.CAR-Ts can reach and eliminate $\mathrm{HL}$ tumor cells. ${ }^{51}$

In a second study conducted at Baylor College of Medicine (BCM), seven patients were treated with CD30.CAR-Ts without previous lymphodepleting chemotherapy. ${ }^{52}$ One patient achieved $\mathrm{CR}$, which has been maintained for $>2.5$ years, whereas another patient, who was in $\mathrm{CR}$ at the time of treatment, continued to be in CR for $>2$ years. There were no toxicities attributed to CD30.CAR-Ts and no impairment of T-cell-mediated immunity, defined as incidence of viral infections and loss of virus-specific T cells, despite that activated T cells can upregulate CD30.52 Phase $\mathrm{Ib} / \mathrm{II}$ trials of the same CD30.CAR-Ts, but preceded by lymphodepletion, were conducted at BCM and UNC and have shown higher response rates in heavily pretreated patients, with CRs seen in more than half treated with optimal lymphodepletion and low rates of toxicity, including CRS $^{53}$ (Table 3). The success of these studies is encouraging for further investigation of CD30.CAR-Ts for patients with $\mathrm{HL}$.
Another target investigated in $\mathrm{HL}$ is $\mathrm{CD} 123$, which is expressed on HRS cells in 50\%-60\% of patients with $\mathrm{HL}$, in addition to immune cells in the HL TME, most importantly tumor-associated macrophages (TAMs). ${ }^{54}$ Preclinical studies of CD123-specific CAR-Ts (CD123.CAR-Ts) have confirmed their antilymphoma activity as well as their ability to eliminate TAMs. ${ }^{55,56}$ However, because CD123 is expressed by myeloid precursors, myelosuppression may represent a serious adverse effect, ${ }^{57}$ and this treatment would likely require a rescue with HSC transplantation. ${ }^{56}$

Future directions. Despite the encouraging high rate of response in patients with $\mathrm{HL}$ receiving CD30.CAR-T cells, relapses still occur. It is encouraging that $\mathrm{HL}$ that relapses after CD30. CAR-T therapy seems to retain CD30 expression. ${ }^{53}$ Thus, tumor recurrence may more likely be related to the inhibitory effects of the TME, suboptimal persistence, or issues with trafficking of CAR-Ts to the tumor site. The unique biology of the TME of HL makes this tumor an excellent model to test some of the issues that CAR-T therapies face and to study the next generation of CAR-T modifications. For example, HRS cells produce thymus and activation-regulated chemokine/CC chemokine ligand 17 and macrophage-derived chemokine to attract suppressive cells that express their cognate receptor CC chemokine receptor 4 (CCR4). ${ }^{58-60}$ In preclinical studies, CD30.CAR-Ts that co-expressed CCR4 showed improved trafficking and antilymphoma activity compared with CD30.CARTs. ${ }^{61}$ There is currently a phase I clinical trial at UNC that is testing the hypothesis that CD30.CAR-Ts co-expressing CCR4 may have improved tumor trafficking in patients with $\mathrm{r} / \mathrm{rHL}$ (Appendix Table A3).

Given the rich inhibitory TME seen in $\mathrm{HL}$, other venues for improvement include combination therapies. Because PD1 is expressed by infused CD30.CAR-Ts, ${ }^{52}$ these cells remain susceptible to the inhibitory effect from PD-L1-expressing HRS cells. ${ }^{62}$ Checkpoint inhibitors, already approved for $\mathrm{HL}$, should interrupt this pathway, improve the expansion and persistence of CAR-Ts, and potentially overcome the inhibitory TME.

\section{T-Cell Malignancies}

The prognosis of patients with relapsed acute T-cell acute lymphoblastic leukemia (T-ALL) and T-cell lymphoma (TCL) is poor with limited treatment options, ${ }^{63,64}$ so there has been interest in developing CAR-T therapies for these malignancies. However, unique challenges when targeting T-cell-associated antigens in T-cell malignancies raise significant concerns in developing CAR-T-based approaches.

The first problem is that targeting T-cell lineage-associated antigens shared by malignant and normal $T$ cells can directly impair the manufacturing of CAR-Ts because of fratricide. ${ }^{3}$ This necessitates the identification of antigens expressed on $\mathrm{T}$ cells but rapidly downregulated upon binding. ${ }^{65}$ CD5 is believed to be one of these antigens. In 
TABLE 3. CD30 CAR-T Clinical Trials for $\mathrm{HL}$ and $\mathrm{CD} 30^{+} \mathrm{NHL}$

\begin{tabular}{|c|c|c|c|c|c|c|c|c|c|c|c|}
\hline Trial Site & Phase & Disease & $\begin{array}{l}\text { No. of } \\
\text { Patients }\end{array}$ & $\begin{array}{l}\text { Median } \\
\text { Lines of } \\
\text { Prior } \\
\text { Therapy }\end{array}$ & $\begin{array}{c}\text { CAR } \\
\text { Generation }\end{array}$ & $\begin{array}{l}\text { Costimulatory } \\
\text { Domain }\end{array}$ & Cell Dose & LD Regimen & $\begin{array}{c}\text { Best } \\
\text { Response }\end{array}$ & $\begin{array}{c}\text { Toxicity } \\
\text { (grade } \geq 3 \text { CRS/ } \\
\text { neurotoxicity) }\end{array}$ & Study \\
\hline $\begin{array}{l}\text { Tessa } \\
\text { Therapeutics }\end{array}$ & II & $\mathrm{HL}$ & 90 & $\geq 3$ & Second & $4-1 B B$ & NA & $\begin{array}{l}\text { Fludarabine and } \\
\text { bendamustine }\end{array}$ & Ongoing & Ongoing & $\begin{array}{l}\text { ClinicalTrials.gov } \\
\text { identifier: } \\
\text { NCT04268706 }\end{array}$ \\
\hline $\begin{array}{c}\text { Chinese PLA } \\
\text { General } \\
\text { Hospital }\end{array}$ & $|/| \mid$ & $\mathrm{HL} / \mathrm{NHL}$ & 30 & $\geq 2^{\mathrm{a}}$ & Second & $4-1 B B$ & $\begin{array}{c}\text { Mean of } \\
1.56 \times \\
10^{7} \\
\text { CAR- } \\
\text { Ts/kg }\end{array}$ & $\begin{array}{l}25 \mathrm{mg} / \mathrm{m}^{2} \text { fludarabine } \\
+30 \mathrm{mg} / \mathrm{kg} \mathrm{Cy}\end{array}$ & $\begin{array}{l}\text { Ongoing, } 7 \\
\text { of } 18 \text { in } \\
\text { PR } \\
6 \text { of } 18 \\
\text { with SD }\end{array}$ & $\begin{array}{l}\text { Ongoing } \\
\text { Of initial } 18 \text { patients, } \\
\text { no grade } 3 / 4 \text { events } \\
\text { reported to date }\end{array}$ & $\begin{array}{l}\text { ClinicalTrials.gov } \\
\text { identifier: } \\
\text { NCT02259556 }\end{array}$ \\
\hline UNC/BCM & $|/| \mid$ & $\mathrm{HL}$ & 42 & 7 & Second & CD28 & $\begin{array}{l}0.2-2 \times \\
10^{8} \\
\text { cells } / \mathrm{m}^{2}\end{array}$ & $\begin{array}{l}\text { Fludarabine and } \\
\text { bendamustine or } \\
\text { fludarabine and } \mathrm{Cy}\end{array}$ & $\begin{array}{r}\text { ORR, 72\%, } \\
\text { CR, 59\% }\end{array}$ & $\begin{array}{l}\text { Grade } \geq 3 \text { CRS, 24\% } \\
\text { No grade } \geq 3 \\
\text { neurotoxicity }\end{array}$ & $\begin{array}{l}\text { ClinicalTrials.gov } \\
\text { identifiers: } \\
\text { NCT02690545 and } \\
\text { NCT02917083 }\end{array}$ \\
\hline $\begin{array}{l}\text { Southwest } \\
\text { Hospital, } \\
\text { China }\end{array}$ & $|/| \mid$ & $\begin{array}{l}\mathrm{CD}^{+} 0^{+} \\
\text {leukemia/ } \\
\text { lymphoma }\end{array}$ & 45 & $r / r$ & $N A$ & NA & NA & NA & Ongoing & Ongoing & $\begin{array}{l}\text { ClinicalTrials.gov } \\
\text { identifier: } \\
\text { NCT02958410 }\end{array}$ \\
\hline UNC & II & $\begin{array}{l}\mathrm{CD}^{+} 0^{+} \mathrm{T} \text {-cell } \\
\text { lymphoma }\end{array}$ & 20 & $r / r, \geq 2$ & Second & CD28 & $\begin{array}{l}2 \times 10^{8} \\
\text { CAR-Ts/ } \\
\mathrm{m}^{2}\end{array}$ & $\begin{array}{l}\text { Fludarabine and } \\
\text { bendamustine then } \\
\text { Cy and fludarabine }\end{array}$ & Ongoing & Ongoing & $\begin{array}{l}\text { ClinicalTrials.gov } \\
\text { identifier: } \\
\text { NCT04083495 }\end{array}$ \\
\hline
\end{tabular}

Abbreviations: BCM, Baylor College of Medicine; CAR, chimeric antigen receptor; CAR-T, chimeric antigen receptor T cell; CR, complete response; CRS, cytokine release syndrome; Cy,

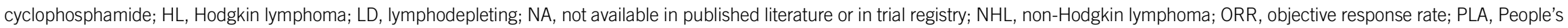
Liberation Army; PR, partial response, r/r, relapsed or refractory; SD, stable disease; UNC, University of North Carolina at Chapel Hill.

${ }^{a}$ Also enrolling newly diagnosed patients not fit for other therapy. 
preclinical models, $T$ cells transduced with a CAR targeting CD5 (CD5.CAR-Ts) experienced only transient fratricide because these $T$ cells subsequently reduced their expression of CD5 while increasing expression of protective molecules that inhibit T-cell-mediated cytotoxicity and apoptosis. ${ }^{65}$ CD5.CAR-Ts eradicated TCL lines and T-ALL blasts in vitro and controlled progression of T-ALL in mouse models. ${ }^{65}$ A clinical trial of CD5.CAR-Ts is currently ongoing ${ }^{66}$ (ClinicalTrials.gov identifier: NCT03081910; Appendix Table A4, online only). Preliminary results suggest safety of this approach, with responses seen in four of nine reported patients, although two patients who did not proceed to HSC transplantation experienced a relapse.

Another method to prevent fratricide effects during CAR-T manufacturing is testing the elimination of the target antigen in CAR-Ts themselves through gene editing. This strategy is being explored for targeting CD7, which is highly expressed by normal T and NK cells without downregulation during CAR-T expansion. ${ }^{67} \mathrm{CRISPR} /$ Cas9 editing to disrupt the CD7 gene before transduction with a CD7directed CAR allowed CAR-T expansion ex vivo without fratricide effects. ${ }^{68}$ Several trials of CD7.CAR-Ts for patients with $\mathrm{CD}^{+}$T-cell malignancies are currently recruiting (Table 4; Appendix Table A4).

The second and most concerning challenge of developing CAR-Ts for T-cell malignancies is the potential deleterious effect of specific CAR-Ts on the normal compartments of $T$ cells and NK cells upon infusion in patients. Edited CD7.CAR-Ts seemed to retain response to viral peptides through their native TCR, which offers hope that infused cells will preserve some pathogen specificity. ${ }^{68}$ However, if T-cell aplasia occurs in case of robust persistence in vivo of CAR-Ts targeting pan-T antigens, patients will be at high risk for life-threatening opportunistic infections. ${ }^{67}$ In consideration of this risk, CAR-Ts that target pan-T antigens may only be indicated as a bridge to allogeneic HSC transplantation. Alternatively, antigens with limited expression on normal $T$ cells compared with malignant $T$ cells should be considered to develop CAR-Ts as a long-term therapy for patients with T-cell malignancies. An example is the CAR specific for the TCR $\beta$-chain constant region domain 1 (TRBC1). ${ }^{69}$ Physiologically, TRBC1 and TRBC2 are expressed on normal $T$ cells, in a mutually exclusive manner, and in a majority of T-cell lymphomas as well as in one third of T-ALL. ${ }^{69}$ Although normal and antigen-specific T-cell populations contain both $\mathrm{TRBC}^{+}$and $\mathrm{TRBC}^{+}$ cells, malignant clones express only either TRBC1 or TRBC2. In preclinical studies, CAR-Ts that target TRBC1 eliminated $\mathrm{TRBC}^{+}$normal and malignant $\mathrm{T}$ cells but preserved $\mathrm{TRBC}^{+}$normal $\mathrm{T}$ cells in vitro and in T-ALL mouse models. ${ }^{69}$ A clinical trial of TRBC1.CAR-T cells for T-cell lymphoma is ongoing (ClinicalTrials.gov identifier: NCT03590574; Table 4).

Another alternative target is CD1a, expressed in cortical T-cell leukemia, that accounts for approximately $40 \%$ of cases of T-ALL, but not on mature T cells. ${ }^{70}$ In preclinical studies, CAR-Ts that target CDla expanded ex vivo without fratricide effects and showed activity against cortical T-cell blasts, while preserving normal T cells. ${ }^{71}$ Although this approach cannot be applied to all T-ALL, it holds promise for cortical T-ALL.

CD30 is another potential target expressed by anaplastic large-cell lymphoma (ALCL) and other peripheral TCLs. ${ }^{72}$ In a phase I clinical trial of CD30.CAR-Ts, one patient with cutaneous ALCL was treated without lymphodepleting chemotherapy with a PR. In a different phase I clinical trial of CD30.CAR-Ts without lymphodepletion, two patients with ALCL were treated, and one patient achieved CR that lasted 9 months. ${ }^{52}$ There are several clinical trials of CD30.CAR-Ts that are enrolling patients with $\mathrm{CD} 30^{+} \mathrm{TCL}$ (Table 3; Appendix Table A3).

A third obstacle in developing CAR-Ts for T-ALL and TCL revolves around the risk of contamination of the CAR-T product with malignant $T$ cells that can be accidentally transduced with a viral vector. ${ }^{3}$ This phenomenon was reported in a patient with $B$-cell ALL who received CD19.CAR-Ts, which included leukemic blasts that inadvertently expressed the CAR. ${ }^{73}$ The presence of the CD19.CAR in cells expressing the same antigen led to the masking of the CD19 epitope, creating a resistant clone able to expand and lead to relapse. While this is a rare occurrence in patients with B-cell malignancies, it seems a more real possibility in patients with $\mathrm{T}$-cell malignancies because $T$ cells are the intended target of transduction and are highly susceptible to vector-mediated gene transfer compared with B cells. As more clinical trials of autologous CAR-Ts for T-cell malignancies are developing, it will be important to consider whether CAR insertion in malignant $T$ cells, in addition to masking antigen recognition, can also cause insertion mutagenesis in tumor cells, exacerbating their malignant phenotype.

Future directions. Patients with T-cell malignancies often have been heavily pretreated and may have low T-cell counts as well as functionally defective $T$ cells. In addition, these patients may have aggressive diseases with a restricted window for receiving treatment. All these aspects make T-cell malignancies an appealing clinical setting to test the use of off-the-shelf CAR-Ts. One example of off-the-shelf CAR-Ts being explored is the UCART7 study in which the deletion of CD7 and TCR through CRISPR/Cas9 gene editing in allogeneic T cells is coupled with CD7.CAR expression. ${ }^{74}$ The UCART7 T-cell product was found to be active against T-ALL without causing fratricide effects or xenogeneic graftversus-host disease. ${ }^{74}$ These universal CAR-Ts are generally expected to have shorter persistence as a result of rejection by host cells. ${ }^{3,74}$ However, this phenomenon may have some advantages in this specific setting given the concerns for immunosuppression when targeting $T$ and NK cells. Universal CAR-Ts for T-cell malignancies are currently being investigated in clinical trials (Appendix Table A4). 
TABLE 4. CAR-T Clinical Trials for T-Cell Malignancies

\begin{tabular}{|c|c|c|c|c|c|c|c|c|c|c|c|}
\hline Target and Trial & Phase & Disease & $\begin{array}{l}\text { No. of } \\
\text { Patients }\end{array}$ & $\begin{array}{c}\text { Median Lines } \\
\text { of Prior } \\
\text { Therapy }\end{array}$ & $\begin{array}{c}\text { CAR } \\
\text { Generation }\end{array}$ & $\begin{array}{l}\text { Costimulatory } \\
\text { Domain }\end{array}$ & Cell Dose & LD Regimen & $\begin{array}{c}\text { Best } \\
\text { Response }\end{array}$ & $\begin{array}{c}\text { Toxicity (grade } \\
\geq 3 \text { CRS/ } \\
\text { neurotoxicity) }\end{array}$ & Study \\
\hline \multicolumn{12}{|l|}{ CD7 } \\
\hline $\begin{array}{l}\text { Shenzhen Geno- } \\
\text { Immune } \\
\text { Medical } \\
\text { Institute }\end{array}$ & $|/| I$ & $\begin{array}{l}\mathrm{CD7}^{+} \mathrm{NK} \text { or } \\
\mathrm{T}^{-c e l l} \\
\text { leukemia/ } \\
\text { lymphoma }\end{array}$ & 30 & $r / r$ & NA & NA & NA & NA & Ongoing & Ongoing & $\begin{array}{l}\text { ClinicalTrials.gov } \\
\text { identifier: } \\
\text { NCT04033302 }\end{array}$ \\
\hline \multicolumn{12}{|l|}{ TRBC1 } \\
\hline Autolus Limited & $|/|||$ & $\begin{array}{l}\text { TRBC1 }^{+} \text {T-cell } \\
\text { Leukemia/ } \\
\text { lymphoma }\end{array}$ & 55 & $r / r$ & NA & NA & $\begin{array}{l}25-225 \times 10^{6} \\
\text { RQR8/ } \\
\text { aTRBC1 CAR-Ts }\end{array}$ & $\begin{array}{c}\text { Fludarabine } \\
\text { and Cy }\end{array}$ & Ongoing & Ongoing & $\begin{array}{l}\text { ClinicalTrials.gov } \\
\text { identifier: } \\
\text { NCT03590574 }\end{array}$ \\
\hline
\end{tabular}

Abbreviations: CAR, chimeric antigen receptor; CAR-T, chimeric antigen receptor T cell; LD, lymphodepleting; NA, not available in published literature or in trial registry; NK, natural killer; r/r, relapsed or refractory. 
Preliminary data were recently reported for TruUCART GC027 (Gracell Biotechnologies, Shanghai, China), another universal CD7.CAR-T platform. ${ }^{75}$ Four of five treated patients achieved minimal residual disease (MRD)-negative CR without subsequent allogeneic HSC transplantation and modest toxicity, including CRS that resolved with treatment and supportive care. Longer follow-up is needed to assess the durability of these responses as well as long-term effects on T-cell immunity.

There has been much progress in the preclinical realm in overcoming the unique obstacles associated with targeting T-cell malignancies with CAR-Ts. In the coming years, we expect to see results of the ongoing clinical trials. Future challenges remain in identifying targets and approaches that can lead to more-prolonged persistence while avoiding intolerable toxicities.

\section{AML}

Developing CAR-Ts for AML has been particularly puzzling because of the difficulty of selecting a suitable antigen not shared by the leukemic blasts and healthy HSCs. ${ }^{1}$ There is a particular concern for significant on-target/off-tumor toxicity leading to life-threatening infections, long-term transfusion requirements, or bleeding complications. ${ }^{76}$ The majority of the work in AML to date has been preclinical, although there have been a few clinical trials with limited data reported (Table 5; Appendix Table A5, online only). The first published clinical trial tested CAR-Ts that targeted the Lewis-Y antigen in AML. This phase I study showed transient clinical responses, and CAR-Ts persisted for up to 10 months without causing severe toxicities. ${ }^{77}$ Two other antigens of particular interest have been CD33 and CD123 because of their almost universal expression on $A M L$ blasts. $^{78}$

In a case report, one patient treated with CD33.CAR-Ts had a very transient reduction of leukemic blasts followed by progression within 9 weeks. $^{79}$ Dual CD33 and CLL-1 (C-type lectin molecule-1).CAR-Ts have been developed in an attempt to improve efficacy and overcome tumor escape. In a preliminary report, two patients with AML achieved MRD-negative CR and subsequently underwent allogeneic HSC transplantation. ${ }^{80}$

There have been two reported clinical trials with CD123.CARTs in AML. In the first trial at the University of Pennsylvania, mRNA electroporated CD123.CAR-Ts were used to assess the safety of targeting CD123. ${ }^{81}$ No significant toxicities were reported, but despite multiple infusions of CD123.CAR-Ts, all five patients progressed before day 28 , and the trial was discontinued because of futility. However, the lack of toxicity supported the development of the subsequent study targeting CD123 using CD123.CAR-Ts in which the CAR is stably expressed by $T$ cells through lentiviral transduction. Another trial of CD123.CAR-Ts obtained through lentiviral transduction is currently ongoing at City of Hope Medical Center. In the preliminary report, two of six treated patients with AML achieved CR and successfully proceeded to allogenic HSC transplantation. ${ }^{82}$ Still, more data are needed to draw conclusions about long-term toxicities in responding patients not eligible for transplantation.

Future directions. Despite the promise of some of the aforementioned approaches, there is still concern about the profound and prolonged myeloablation after CAR-Ts targeting myeloid-associated antigens, and alternative methods are urgently needed to minimize on-target/offtumor toxicity. Novel approaches include using gene editing to remove the AML-specific antigen from normal cells. ${ }^{76}$ In preclinical models, CRISPR/Cas9 gene editing was successful in creating CD33-deficient HSCs that are resistant to CD33.CAR-Ts but still have normal hematologic and immunologic function. ${ }^{83}$ However, the clinical feasibility of this complex procedure remains a major concern. Alternative approaches consider the targeting of multiple antigens that must be simultaneously expressed by leukemic blasts and not by normal HSCs to fully activate CARTs. $^{84,85}$

\section{DISCUSSION}

There have been promising developments in CAR-Ts for non-CD19-expressing hematologic malignancies. BCMA.CAR-Ts for MM are farthest along, with upcoming US Food and Drug Administration approval. Approaches for other hematologic diseases such as HL have also recently made significant progress. Toxicities of BCMA.CAR-Ts in $\mathrm{MM}$, such as CRS and neurotoxicity, seem similar to those observed with CD19.CAR-Ts in B-cell malignancies. In contrast, targets such as CD30 in HL showed limited incidence of CRS and no neurotoxicity. Additional studies are needed to determine the etiology of these differences, which are likely multifactorial and related to antigen specificity, CAR construct design, and disease type. As these novel CAR-Ts move to the clinic, challenges remain, including mitigating on-target/off-tumor toxicities either through antigen selection or logic-gating strategies, ${ }^{86}$ understanding resistance to treatment, addressing manufacturing limitations in heavily pretreated patients, and reducing the high costs. We anticipate continued development of novel approaches to meet these obstacles and enhance the effectiveness of CAR-Ts.

In conclusion, while targeting CD19 has driven the field of CAR-Ts, recent advances support the notion that CAR-T technology can be applied to other targets and to other hematologic diseases. It is, however, also becoming evident that by moving away from B-cell malignancies, we also face more challenges related to both CAR-T manufacturing and the complexity of the TME. Ongoing work will continue to inspire researchers to further advance CAR-T cells and hopefully move into the arena of solid tumors. 
TABLE 5. CAR-T Clinical Trials for AML

\begin{tabular}{|c|c|c|c|c|c|c|c|c|c|c|c|}
\hline Target and Trial & Phase & Disease & $\begin{array}{c}\text { No. of } \\
\text { Patients }\end{array}$ & $\begin{array}{l}\text { Median } \\
\text { Lines of } \\
\text { Prior } \\
\text { Therapy }\end{array}$ & $\begin{array}{c}\text { CAR } \\
\text { Generation }\end{array}$ & $\begin{array}{l}\text { Costimulatory } \\
\text { Domain }\end{array}$ & Cell Dose & LD Regimen & $\begin{array}{c}\text { Best } \\
\text { Response }\end{array}$ & $\begin{array}{l}\text { Toxicity (grade } \\
\geq 3 \text { CRS/ } \\
\text { neurotoxicity) }\end{array}$ & Study \\
\hline \multicolumn{12}{|l|}{ CD33 } \\
\hline CIBMTR & I/II & $\mathrm{CD} 33^{+} \mathrm{AML}$ & 34 & $r / r, \geq 1$ & NA & NA & $\begin{array}{l}\text { Starting dose: } 3 \times \\
10^{5} \text { transduced } \\
\text { CAR-Ts/kg }\end{array}$ & $\begin{array}{l}3 \text { days fludarabine } \\
25 \mathrm{mg} / \mathrm{m}^{2} / \text { dose, } 1 \text { day } \\
\text { Cy } 900 \mathrm{mg} / \mathrm{m}^{2} / \text { dose }\end{array}$ & Ongoing & Ongoing & $\begin{array}{l}\text { ClinicalTrials.gov } \\
\text { identifier: } \\
\text { NCT03971799 } \\
\end{array}$ \\
\hline $\begin{array}{l}\text { Southwest } \\
\text { Hospital, } \\
\text { China }\end{array}$ & I/II & $\begin{array}{l}\mathrm{CD}^{\mathrm{C}} 3^{+} \text {myeloid } \\
\text { malignancy }\end{array}$ & 45 & $r / r$ & NA & NA & NA & NA & Ongoing & Ongoing & $\begin{array}{l}\text { ClinicalTrials.gov } \\
\text { identifier: } \\
\text { NCT02958397 }\end{array}$ \\
\hline \multicolumn{12}{|l|}{$\mathrm{CD} 123^{\mathrm{a}}$} \\
\hline $\begin{array}{l}\text { Chongqing } \\
\text { Precision } \\
\text { Biotech }\end{array}$ & $\mid / I I$ & $\mathrm{CD}_{123^{+}} \mathrm{AML}$ & 40 & $r / r$ & NA & NA & NA & NA & Ongoing & Ongoing & $\begin{array}{l}\text { ClinicalTrials.gov } \\
\text { identifier: } \\
\text { NCT04272125 }\end{array}$ \\
\hline $\begin{array}{l}\text { Chongqing } \\
\text { Precision } \\
\text { Biotech }\end{array}$ & $|/ I|$ & $\mathrm{CD} 123^{+} \mathrm{AML}$ & 45 & $r / r, \geq 2$ & NA & NA & NA & NA & Ongoing & Ongoing & $\begin{array}{l}\text { ClinicalTrials.gov } \\
\text { identifier: } \\
\text { NCT04265963 }\end{array}$ \\
\hline $\begin{array}{l}\text { Southwest } \\
\text { Hospital, } \\
\text { China }\end{array}$ & $\mid / I I$ & $\begin{array}{l}\mathrm{CD}^{\mathrm{C}} 123^{+} \text {myeloid } \\
\text { malignancy }\end{array}$ & 45 & $r / r$ & NA & NA & NA & NA & Ongoing & Ongoing & $\begin{array}{l}\text { ClinicalTrials.gov } \\
\text { identifier: } \\
\text { NCT02937103 }\end{array}$ \\
\hline Mustang Bio & $|/| \mid$ & $\begin{array}{l}\mathrm{CD} 123^{+} \mathrm{MDS} / \\
\mathrm{AML} / \mathrm{BPDCN}\end{array}$ & 126 & $\begin{array}{l}\text { r/r BPDCN/ } \\
\text { AML or } \\
\text { high-risk } \\
\text { MDS }\end{array}$ & Second & CD28 & $\begin{array}{l}\text { Maximum: } 600 \times \\
10^{6} \text { CAR-Ts }\end{array}$ & $\begin{array}{l}5 \text { days } 20 \mathrm{mg} / \mathrm{m}^{2} \\
\text { decitabine, } \\
\text { fludarabine } 30 \mathrm{mg} / \mathrm{m}^{2} / \\
\text { d, } 3 \text { days of Cy } 300- \\
500 \mathrm{mg} / \mathrm{m}^{2} / \mathrm{d}\end{array}$ & Ongoing & Ongoing & $\begin{array}{l}\text { ClinicalTrials.gov } \\
\text { identifier: } \\
\text { NCT04109482 }\end{array}$ \\
\hline \multicolumn{12}{|l|}{ CLL1/CD123 } \\
\hline $\begin{array}{l}\text { Fujian Medical } \\
\text { University }\end{array}$ & $\|/\| \|$ & AML & 20 & $r / r$ & NA & NA & NA & NA & Ongoing & Ongoing & $\begin{array}{l}\text { ClinicalTrials.gov } \\
\text { identifier: } \\
\text { NCT03631576 } \\
\end{array}$ \\
\hline \multicolumn{12}{|l|}{$\begin{array}{r}\text { CLL1/CD33/ } \\
\text { CD123 }\end{array}$} \\
\hline $\begin{array}{l}\text { Shenzhen } \\
\text { Geno- } \\
\text { Immune } \\
\text { Medical } \\
\text { Institute }\end{array}$ & $|/| I$ & $\begin{array}{l}\mathrm{CLL1}^{+} \text {and/or } \\
\mathrm{CD} 33^{+} \text {and/or } \\
\mathrm{CD} 23^{+} \mathrm{AML}\end{array}$ & 10 & $r / r$ & NA & NA & NA & NA & Ongoing & Ongoing & $\begin{array}{l}\text { ClinicalTrials.gov } \\
\text { identifier: } \\
\text { NCT04010877 }\end{array}$ \\
\hline & & & & & & (continued on & ollowing page) & & & & \\
\hline
\end{tabular}


Median

\begin{tabular}{|c|c|c|c|c|c|c|c|c|c|c|c|}
\hline Target and Trial & Phase & Disease & $\begin{array}{l}\text { No. of } \\
\text { Patients }\end{array}$ & $\begin{array}{l}\text { Lines of } \\
\text { Prior } \\
\text { Therapy }\end{array}$ & $\begin{array}{c}\text { CAR } \\
\text { Generation }\end{array}$ & $\begin{array}{l}\text { Costimulatory } \\
\text { Domain }\end{array}$ & Cell Dose & LD Regimen & $\begin{array}{c}\text { Best } \\
\text { Response }\end{array}$ & $\begin{array}{c}\text { Toxicity (grade } \\
\geq 3 \text { CRS/ } \\
\text { neurotoxicity) }\end{array}$ & Study \\
\hline \multicolumn{12}{|l|}{ CD38 } \\
\hline $\begin{array}{c}\text { First Affiliated } \\
\text { Hospital of } \\
\text { Soochow } \\
\text { University }\end{array}$ & I/II & $\mathrm{CD}^{2} 8^{+} \mathrm{AML}$ & 20 & $r / r$ & NA & NA & $\begin{array}{c}5-20 \times 10^{6} \mathrm{CAR}- \\
\mathrm{T}-38 \text { cells } / \mathrm{kg}\end{array}$ & NA & Ongoing & Ongoing & $\begin{array}{l}\text { ClinicalTrials.gov } \\
\text { identifier: } \\
\text { NCT04351022 }\end{array}$ \\
\hline \multicolumn{12}{|l|}{$\mathrm{CD}_{4} 4^{\mathrm{b}}$} \\
\hline $\begin{array}{l}\text { Molecular } \\
\text { Medicine }\end{array}$ & |//I & $\begin{array}{l}\mathrm{CD} 44 \mathrm{v} 6^{+} \mathrm{AML} \\
\mathrm{MM}\end{array}$ & 58 & $r / r$ & NA & NA & $\begin{array}{c}0.5,1, \text { or } 2 \times \\
10^{6} / \mathrm{kg}\end{array}$ & Fludarabine and Cy & Ongoing & Ongoing & $\begin{array}{l}\text { ClinicalTrials.gov } \\
\text { identifier: } \\
\text { NCT04097301 }\end{array}$ \\
\hline
\end{tabular}

Abbreviations: AML, acute myelogenous leukemia; BPDCN, blastic plasmacytoid dendritic cell neoplasma; CAR, chimeric antigen receptor; CAR-T, chimeric antigen receptor T cell; CIBMTR, Center for

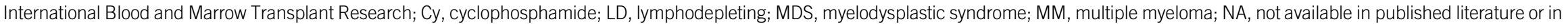
trial registry; $r / r$, relapsed or refractory.

aBiodegradable T electroporated with anti-CD123 CAR mRNA.

bHSV-TK Mut2 gene (suicide gene). 


\section{AFFILIATIONS}

${ }^{1}$ Lineberger Comprehensive Cancer Center, The University of North Carolina at Chapel Hill, Chapel Hill, NC

2Department of Medicine, The University of North Carolina at Chapel Hill, Chapel Hill, NC

${ }^{3}$ Departments of Immunology and Microbiology, The University of North Carolina at Chapel Hill, Chapel Hill, NC

${ }^{4}$ Department of Pediatrics, The University of North Carolina at Chapel Hill, Chapel Hill, NC

\section{CORRESPONDING AUTHOR}

Barbara Savoldo, MD, PhD, Lineberger Comprehensive Cancer Center, The University of North Carolina at Chapel Hill, 125 Mason Farm Rd, Marsico Hall, Suite 5203, Chapel Hill, NC 27599; e-mail: bsavoldo@ med.unc.edu.

\section{SUPPORT}

Supported by Lineberger Comprehensive Cancer Center, The University of North Carolina Oncology, Grant No. K12-CA120780 (N.S.G.) and by a Lymphoma Research Foundation Career Development Award. N.T. is supported by National Cancer Institute (NCI) Grant No. T32-CA211056. G.D. is supported by NCl Grants No. R01-CA193140-03, R01CA243543-01, and R21-CA229938-01A1 and by American Association for Cancer Research Stand Up to Cancer. B.S. is supported by NCI Grants No. R01-CA247497 and U01-CA239258.

\section{AUTHORS' DISCLOSURES OF POTENTIAL CONFLICTS OF INTEREST}

Disclosures provided by the authors are available with this article at DOI https://doi.org/10.1200/JC0.20.01738.

\author{
AUTHOR CONTRIBUTIONS \\ Conception and design: All authors \\ Collection and assembly of data: Natalie S. Grover \\ Data analysis and interpretation: Natalie S. Grover \\ Manuscript writing: All authors \\ Final approval of manuscript: All authors \\ Accountable for all aspects of the work: All authors
}

\section{REFERENCES}

1. Holstein SA, Lunning MA: CAR T-cell therapy in hematologic malignancies: A voyage in progress. Clin Pharmacol Ther 107:112-122, 2020

2. Scheuermann RH, Racila E: CD19 antigen in leukemia and lymphoma diagnosis and immunotherapy. Leuk Lymphoma 18:385-397, 1995

3. Alcantara M, Tesio M, June CH, et al: CAR T-cells for T-cell malignancies: Challenges in distinguishing between therapeutic, normal, and neoplastic T-cells. Leukemia 32:2307-2315, 2018

4. Garfall AL, Maus MV, Hwang W-T, et al: Chimeric antigen receptor T cells against CD19 for multiple myeloma. N Engl J Med 373:1040-1047, 2015

5. Garfall AL, Stadtmauer EA, Hwang WT, et al: Anti-CD19 CAR T cells with high-dose melphalan and autologous stem cell transplantation for refractory multiple myeloma. JCl Insight 3:e120505, 2018

6. Cho SF, Anderson KC, Tai YT: Targeting B cell maturation antigen (BCMA) in multiple myeloma: Potential uses of BCMA-based immunotherapy. Front Immunol 9:1821, 2018

7. Avery DT, Kalled SL, Ellyard JI, et al: BAFF selectively enhances the survival of plasmablasts generated from human memory B cells. J Clin Invest 112:286-297, 2003

8. O'Connor BP, Raman VS, Erickson LD, et al: BCMA is essential for the survival of long-lived bone marrow plasma cells. J Exp Med 199:91-98, 2004

9. Carpenter RO, Evbuomwan MO, Pittaluga S, et al: B-cell maturation antigen is a promising target for adoptive T-cell therapy of multiple myeloma. Clin Cancer Res 19:2048-2060, 2013

10. Novak AJ, Darce JR, Arendt BK, et al: Expression of BCMA, TACI, and BAFF-R in multiple myeloma: A mechanism for growth and survival. Blood 103:689-694, 2004

11. Ali SA, Shi V, Maric I, et al: T cells expressing an anti-B-cell maturation antigen chimeric antigen receptor cause remissions of multiple myeloma. Blood 128: $1688-1700,2016$

12. Cohen AD, Garfall AL, Stadtmauer EA, et al: B cell maturation antigen-specific CAR T cells are clinically active in multiple myeloma. J Clin Invest 129: 2210-2221, 2019

13. Raje N, Berdeja J, Lin Y, et al: Anti-BCMA CAR T-cell therapy bb2121 in relapsed or refractory multiple myeloma. N Engl J Med 380:1726-1737, 2019

14. Zhao WH, Liu J, Wang BY, et al: A phase 1, open-label study of LCAR-B38M, a chimeric antigen receptor T cell therapy directed against B cell maturation antigen, in patients with relapsed or refractory multiple myeloma. J Hematol Oncol 11:141, 2018

15. Mailankody S, Ghosh A, Staehr M, et al: Clinical responses and pharmacokinetics of MCARH171, a human-derived BCMA targeted CAR T cell therapy in relapsed/refractory multiple myeloma: Final results of a phase I clinical trial. Blood 132, 2018 (suppl; abstr 959)

16. Mailankody S, Htut M, Lee KP, et al: JCARH125, Anti-BCMA CAR T-cell therapy for relapsed/refractory multiple myeloma: Initial proof of concept results from a phase 1/2 multicenter study (EVOLVE). Blood 132, 2018 (suppl; abstr 957)

17. Green DJ, Pont M, Sather BD, et al: Fully human BCMA targeted chimeric antigen receptor T cells administered in a defined composition demonstrate potency at low doses in advanced stage high risk multiple myeloma. Blood 132, 2018 (suppl; abstr 1011)

18. Gregory T, Cohen AD, Costello CL, et al: Efficacy and safety of P-BCMA-101 CAR-T cells in patients with relapsed/refractory (r/r) multiple myeloma (MM). http:// cms.cws.net/content/beta.myelomasociety.org/files/2018ash/P-BCMA-101\%20ASH18\%20181203.pdf

19. Laurent SA, Hoffmann FS, Kuhn PH, et al: $\gamma$-Secretase directly sheds the survival receptor BCMA from plasma cells. Nat Commun 6:7333, 2015

20. Pont MJ, Hill T, Cole GO, et al: $\gamma$-Secretase inhibition increases efficacy of BCMA-specific chimeric antigen receptor T cells in multiple myeloma. Blood 134: 1585-1597, 2019

21. O'Connell FP, Pinkus JL, Pinkus GS: CD138 (syndecan-1), a plasma cell marker immunohistochemical profile in hematopoietic and nonhematopoietic neoplasms. Am J Clin Pathol 121:254-263, 2004

22. Kawano $\mathrm{Y}$, Fujiwara S, Wada N, et al: Multiple myeloma cells expressing low levels of CD138 have an immature phenotype and reduced sensitivity to lenalidomide. Int J Oncol 41:876-884, 2012

23. Sun C, Mahendravada A, Ballard B, et al: Safety and efficacy of targeting CD138 with a chimeric antigen receptor for the treatment of multiple myeloma. Oncotarget 10:2369-2383, 2019

24. Guo B, Chen M, Han Q, et al: CD138-directed adoptive immunotherapy of chimeric antigen receptor (CAR)-modified T cells for multiple myeloma. J Cell Immunother 2:28-35, 2016

25. Morandi F, Horenstein AL, Costa F, et al: CD38: A target for immunotherapeutic approaches in multiple myeloma. Front Immunol 9:2722, 2018 
26. Drent E, Groen RWJ, Noort WA, et al: Pre-clinical evaluation of CD38 chimeric antigen receptor engineered T cells for the treatment of multiple myeloma. Haematologica 101:616-625, 2016

27. Drent $\mathrm{E}$, Themeli M, Poels R, et al: A rational strategy for reducing on-target off-tumor effects of CD38-chimeric antigen receptors by affinity optimization. Mol Ther 25:1946-1958, 2017

28. Hsi ED, Steinle R, Balasa B, et al: CS1, a potential new therapeutic antibody target for the treatment of multiple myeloma. Clin Cancer Res 14:2775-2784, 2008

29. Chu J, He S, Deng Y, et al: Genetic modification of T cells redirected toward CS1 enhances eradication of myeloma cells. Clin Cancer Res 20:3989-4000, 2014

30. Gogishvili T, Danhof S, Prommersberger S, et al: SLAMF7-CAR T cells eliminate myeloma and confer selective fratricide of SLAMF7+ ${ }^{+}$normal lymphocytes. Blood 130:2838-2847, 2017

31. Zah E, Nam E, Bhuvan V, et al: Systematically optimized BCMA/CS1 bispecific CAR-T cells robustly control heterogeneous multiple myeloma. Nat Commun 11: 2283, 2020

32. Song W, Gui M, Wang X, et al: Cryo-EM structure of the SARS coronavirus spike glycoprotein in complex with its host cell receptor ACE2. PLoS Pathog 14: e1007236, 2018

33. Casucci M, Nicolis di Robilant B, Falcone L, et al: CD44v6-targeted T cells mediate potent antitumor effects against acute myeloid leukemia and multiple myeloma. Blood 122:3461-3472, 2013

34. Porcellini S, Asperti C, Corna S, et al: CAR T cells redirected to CD44v6 control tumor growth in lung and ovary adenocarcinoma bearing mice. Front Immunol $11: 99,2020$

35. Smith EL, Harrington $\mathrm{K}$, Staehr M, et al: CAR T cell therapy targeting G protein-coupled receptor class C group 5 member D (GPRC5D), a novel target for the immunotherapy of multiple myeloma. Blood 132, 2018 (suppl; abstr 589)

36. Kodama T, Kochi Y, Nakai W, et al: Anti-GPRC5D/CD3 bispecific T-cell-redirecting antibody for the treatment of multiple myeloma. Mol Cancer Ther 18: 1555-1564, 2019

37. Patel K, Olivares S, Singh $\mathrm{H}$, et al: Combination immunotherapy with NY-ESO-1-specific CAR + T cells with T-cell vaccine improves anti-myeloma effect. Blood 128, 2016 (suppl; abstr 3366)

38. Stojanovic A, Correia MP, Cerwenka A: The NKG2D/NKG2DL axis in the crosstalk between lymphoid and myeloid cells in health and disease. Front Immunol 9: 827, 2018

39. Murad JM, Graber DJ, Sentman CL: Advances in the use of natural receptor- or ligand-based chimeric antigen receptors (CARs) in haematologic malignancies. Best Pract Res Clin Haematol 31:176-183, 2018

40. Baumeister SH, Murad J, Werner L, et al: Phase I trial of autologous CAR T cells targeting NKG2D ligands in patients with AML/MDS and multiple myeloma. Cancer Immunol Res 7:100-112, 2019

41. Tassone P, Gozzini A, Goldmacher V, et al: In vitro and in vivo activity of the maytansinoid immunoconjugate huN901-N2'-deacetyl-N2'-(3-mercapto-1oxopropyl)-maytansine against CD56+ multiple myeloma cells. Cancer Res 64:4629-4636, 2004

42. Benjamin R, Condomines M, Gunset G, et al: CD56 targeted chimeric antigen receptors for immunotherapy of multiple myeloma. Cancer Res 72, 2012 (suppl; abstr 3499)

43. Hosen N, Matsunaga $\mathrm{Y}$, Hasegawa $\mathrm{K}$, et al: The activated conformation of integrin $\beta_{7}$ is a novel multiple myeloma-specific target for CAR T cell therapy. Nat Med 23:1436-1443, 2017

44. Greaves P, Clear A, Coutinho R, et al: Expression of FOXP3, CD68, and CD20 at diagnosis in the microenvironment of classical Hodgkin lymphoma is predictive of outcome. J Clin Oncol 31:256-262, 2013

45. Strati $\mathrm{P}$, Fanale MA, Oki Y, et al: ABVD plus rituximab versus ABVD alone for advanced stage, high-risk classical Hodgkin lymphoma: A randomized phase 2 study. Haematologica 104:e65-e67, 2019

46. Svoboda J, Rheingold SR, Gill SI, et al: Nonviral RNA chimeric antigen receptor-modified T cells in patients with Hodgkin lymphoma. Blood 132:1022-1026, 2018

47. Dürkop H, Latza $\mathrm{U}$, Hummel M, et al: Molecular cloning and expression of a new member of the nerve growth factor receptor family that is characteristic for Hodgkin's disease. Cell 68:421-427, 1992

48. Stein H, Mason DY, Gerdes J, et al: The expression of the Hodgkin's disease associated antigen Ki-1 in reactive and neoplastic lymphoid tissue: Evidence that Reed-Sternberg cells and histiocytic malignancies are derived from activated lymphoid cells. Blood 66:848-858, 1985

49. Hombach A, Heuser C, Sircar R, et al: An anti-CD30 chimeric receptor that mediates CD3-zeta-independent T-cell activation against Hodgkin's lymphoma cells in the presence of soluble CD30. Cancer Res 58:1116-1119, 1998

50. Younes A, Gopal AK, Smith SE, et al: Results of a pivotal phase II study of brentuximab vedotin for patients with relapsed or refractory Hodgkin's lymphoma. J Clin Oncol 30:2183-2189, 2012

51. Wang CM, Wu ZQ, Wang Y, et al: Autologous T cells expressing CD30 chimeric antigen receptors for relapsed or refractory Hodgkin lymphoma: An open-label phase I trial. Clin Cancer Res 23:1156-1166, 2017

52. Ramos CA, Ballard B, Zhang H, et al: Clinical and immunological responses after CD30-specific chimeric antigen receptor-redirected lymphocytes. J Clin Invest 127:3462-3471, 2017

53. Ramos CA, Grover NS, Beaven AW, et al: Anti-CD30 CAR-T cell therapy in relapsed and refractory Hodgkin lymphoma. J Clin Oncol 38:3794-3804, 2020

54. Fromm JR: Flow cytometric analysis of CD123 is useful for immunophenotyping classical Hodgkin lymphoma. Cytometry B Clin Cytom 80:91-99, 2011

55. Ruella M, Kenderian SS, Shestova O, et al: Novel chimeric antigen receptor T Cells for the treatment of Hodgkin lymphoma. Blood 124, 2014 (suppl; abstr 806)

56. Ruella M, Klichinsky M, Kenderian SS, et al: Overcoming the immunosuppressive tumor microenvironment of Hodgkin lymphoma using chimeric antigen receptor T cells. Cancer Discov 7:1154-1167, 2017

57. Gill S, Tasian SK, Ruella M, et al: Preclinical targeting of human acute myeloid leukemia and myeloablation using chimeric antigen receptor-modified T cells. Blood 123:2343-2354, 2014 [Erratum: Blood 128:2585, 2016]

58. van den Berg A, Visser L, Poppema S: High expression of the CC chemokine TARC in Reed-Sternberg cells. A possible explanation for the characteristic T-cell infiltratein Hodgkin's lymphoma. Am J Pathol 154:1685-1691, 1999

59. Ishida T, Ishii T, Inagaki A, et al: Specific recruitment of CC chemokine receptor 4-positive regulatory T cells in Hodgkin lymphoma fosters immune privilege. Cancer Res 66:5716-5722, 2006

60. Steidl C, Lee T, Shah SP, et al: Tumor-associated macrophages and survival in classic Hodgkin's lymphoma. N Engl J Med 362:875-885, 2010

61. Di Stasi A, De Angelis B, Rooney CM, et al: T lymphocytes coexpressing CCR4 and a chimeric antigen receptor targeting CD30 have improved homing and antitumor activity in a Hodgkin tumor model. Blood 113:6392-6402, 2009

62. Liu WR, Shipp MA: Signaling pathways and immune evasion mechanisms in classical Hodgkin lymphoma. Hematology (Am Soc Hematol Educ Program) 2017: 310-316, 2017 
63. Litzow MR, Ferrando AA: How I treat T-cell acute lymphoblastic leukemia in adults. Blood 126:833-841, 2015

64. Moskowitz AJ, Lunning MA, Horwitz SM: How I treat the peripheral T-cell lymphomas. Blood 123:2636-2644, 2014

65. Mamonkin M, Rouce RH, Tashiro H, et al: A T-cell-directed chimeric antigen receptor for the selective treatment of T-cell malignancies. Blood 126:983-992, 2015

66. Hill LC, Rouce RH, Smith TS, et al: Safety and anti-tumor activity of CD5 CAR T-cells in patients with relapsed/refractory T-cell malignancies. Blood 134, 2019 (suppl; abstr 199)

67. Fleischer LC, Spencer HT, Raikar SS: Targeting T cell malignancies using CAR-based immunotherapy: Challenges and potential solutions. J Hematol Oncol 12: 141,2019

68. Gomes-Silva D, Srinivasan M, Sharma S, et al: CD7-edited T cells expressing a CD7-specific CAR for the therapy of T-cell malignancies. Blood 130:285-296, 2017

69. Maciocia PM, Wawrzyniecka PA, Philip B, et al: Targeting the T cell receptor $\beta$-chain constant region for immunotherapy of T cell malignancies. Nat Med 23: 1416-1423, 2017

70. Maciocia PM, Pule MA: Anti-CD1a CAR T cells to selectively target T-ALL. Blood 133:2246-2247, 2019

71. Sánchez-Martínez D, Baroni ML, Gutierrez-Agüera F, et al: Fratricide-resistant CD1a-specific CAR T cells for the treatment of cortical T-cell acute lymphoblastic leukemia. Blood 133:2291-2304, 2019

72. Falini B, Pileri S, Pizzolo G, et al: CD30 (Ki-1) molecule: A new cytokine receptor of the tumor necrosis factor receptor superfamily as a tool for diagnosis and immunotherapy. Blood 85:1-14, 1995

73. Ruella $\mathrm{M}, \mathrm{Xu}$ J, Barrett DM, et al: Induction of resistance to chimeric antigen receptor T cell therapy by transduction of a single leukemic B cell. Nat Med 24: 1499-1503, 2018

74. Cooper ML, Choi J, Staser K, et al: An "off-the-shelf" fratricide-resistant CAR-T for the treatment of T cell hematologic malignancies. Leukemia 32:1970-1983, 2018

75. Wang X, Li S, Gao L, et al: Safety and efficacy results of GC027: The first-in-human, universal CAR-T cell therapy for adult relapsed/refractory T-cell acute lymphoblastic leukemia (r/r T-ALL). J Clin Oncol 38, 2020 (suppl; abstr 2013)

76. Mardiana S, Gill S: CAR T Cells for acute myeloid leukemia: State of the art and future directions. Front Oncol 10:697, 2020

77. Ritchie DS, Neeson PJ, Khot A, et al: Persistence and efficacy of second generation CAR T cell against the LeY antigen in acute myeloid leukemia. Mol Ther 21: 2122-2129, 2013

78. Ehninger A, Kramer M, Röllig C, et al: Distribution and levels of cell surface expression of CD33 and CD123 in acute myeloid leukemia. Blood Cancer J 4:e218, 2014

79. Wang QS, Wang Y, Lv HY, et al: Treatment of CD33-directed chimeric antigen receptor-modified T cells in one patient with relapsed and refractory acute myeloid leukemia. Mol Ther 23:184-191, 2015

80. Liu F, Cao Y, Pinz K, et al: First-in-human CLL1-CD33 compound CAR T cell therapy induces complete remission in patients with refractory acute myeloid leukemia: Update on phase 1 clinical trial. Blood 132, 2018 (suppl; abstr 901)

81. Cummins KD, Frey N, Nelson AM, et al: Treating relapsed/refractory (RR) AML with biodegradable anti-CD123 CAR modified T cells. Blood 130:1359, 2017

82. Budde L, Song JY, Kim Y, et al: Remissions of acute myeloid leukemia and blastic plasmacytoid dendritic cell neoplasm following treatment with CD123-specific CAR T cells: A first-in-human clinical trial. Blood 130:811, 2017

83. Kim MY, Yu K-R, Kenderian SS, et al: Genetic inactivation of CD33 in hematopoietic stem cells to enable CAR T cell immunotherapy for acute myeloid leukemia. Cell 173:1439-1453.e19, 2018

84. Daver N: A bispecific approach to improving CAR T cells in AML. Blood 135:703-704, 2020

85. He X, Feng Z, Ma J, et al: Bispecific and split CAR T cells targeting CD13 and TIM3 eradicate acute myeloid leukemia. Blood 135:713-723, 2020

86. Srivastava S, Salter Al, Liggitt D, et al: Logic-gated ROR1 chimeric antigen receptor expression rescues T cell-mediated toxicity to normal tissues and enables selective tumor targeting. Cancer Cell 35:489-503.e8, 2019 
AUTHORS' DISCLOSURES OF POTENTIAL CONFLICTS OF INTEREST

\section{Extending the Promise of Chimeric Antigen Receptor T-Cell Therapy Beyond Targeting CD19+ Tumors}

The following represents disclosure information provided by authors of this manuscript. All relationships are considered compensated unless otherwise noted. Relationships are self-held unless noted. I = Immediate Family Member, Inst = My Institution. Relationships may not relate to the subject matter of this manuscript. For more information about ASCO's conflict of interest policy, please refer to www.asco.org/rwc or ascopubs.org/jco/authors/author-center.

Open Payments is a public database containing information reported by companies about payments made to US-licensed physicians (Open Payments).

\section{Natalie S. Grover}

Stock and Other Ownership Interests: Sangamo Therapeutics

Consulting or Advisory Role: Seattle Genetics, Tessa Therapeutics, Kite Research Funding: Genentech

Uncompensated Relationships: Tessa Therapeutics

Nicholas Tschernia

Research Funding: AstraZeneca, Medlmmune

Gianpietro Dotti

Consulting or Advisory Role: Molmed, Bellicum Pharmaceutical, Tessa Therapeutics

Research Funding: Bellicum Pharmaceuticals, Cell Medica

Patents, Royalties, Other Intellectual Property: Patents in the field of T/NKT-cell therapies and royalties derived from licensed patents.
Barbara Savoldo

Consulting or Advisory Role: Tessa Therapeutics

Research Funding: Cell Medica, bluebird bio, Bellicum Pharmaceuticals, Tessa Therapeutics

Patents, Royalties, Other Intellectual Property: Patent filed for some CAR molecules (I)

No other potential conflicts of interest were reported. 


\section{APPENDIX}

TABLE A1. BCMA CAR-T Clinical Trials for Multiple Myeloma

\begin{tabular}{|c|c|c|c|c|c|c|c|c|c|c|c|}
\hline Trial & Phase & $\begin{array}{l}\text { No. of } \\
\text { Patients }\end{array}$ & $\begin{array}{l}\text { Median Lines } \\
\text { of Prior } \\
\text { Therapy }\end{array}$ & $\begin{array}{c}\text { CAR } \\
\text { Generation }\end{array}$ & $\begin{array}{l}\text { Costimulatory } \\
\text { Domain }\end{array}$ & Cell Dose & LD Regimen & Best Response & $\begin{array}{l}\text { Toxicity } \\
\text { (grade } \geq 3 \text { CRS/ } \\
\text { neurotoxicity) }\end{array}$ & Status & Study \\
\hline $\mathrm{NCl}$ & I & 24 & 9.5 & Second & CD28 & $\begin{array}{l}0.3,1,3 \text {, or } 9 \times 10^{6} \\
\text { CAR-TS/kg }\end{array}$ & $\begin{array}{l}3 \text { doses of } 300 \mathrm{mg} / \mathrm{m}^{2} \mathrm{Cy} \\
\text { and of } 30 \mathrm{mg} / \mathrm{m}^{2} \\
\text { fludarabine }\end{array}$ & $\begin{array}{l}\text { ORR, } 81 \% \\
63 \% \text { in VGPR or CR } \\
\mathrm{mEFS}, 31 \text { weeks }\end{array}$ & $\begin{array}{l}\text { Grade } \geq 3 \text { CRS, } 6 \text { of } 24 \\
\text { Grade } \geq 3 \text { neurotoxicity, } \\
1 \text { of } 24\end{array}$ & Completed & $\begin{array}{l}\text { ClinicalTrials.gov identifier: } \\
\text { NCT02215967 }\end{array}$ \\
\hline $\begin{array}{l}\text { UPenn/Novartis/NIH } \\
\text { (CART-BCMA) }\end{array}$ & 1 & $\begin{array}{l}25 \text { (in three } \\
\text { cohorts) }\end{array}$ & 7 & Second & $4-1 B B$ & $\begin{array}{l}\text { C1: } 1-5 \times 10^{8} \text { CAR }^{+} \\
\text {cells alone } \\
\text { C2: } 1-5 \times 10^{7} \text { CAR- } \\
\text { Ts }+\mathrm{LD} \\
\text { C3: } 1-5 \times 10^{8} \text { CAR- } \\
\text { Ts }+ \text { LD }\end{array}$ & 1 dose of $1.5 \mathrm{~g} / \mathrm{m}^{2} \mathrm{Cy}$ & $\begin{array}{l}\text { ORR, } 48 \% \\
12 \text { PR or better } \\
3 \text { remissions }>11 \text { months, } \\
\text { including } 1 \mathrm{sCR}>2.5 \text { years }\end{array}$ & $\begin{array}{l}\text { Grade } \geq 3 \text { CRS, } 8 \text { ( } 32 \%) \\
\text { Grade } \geq 3 \text { neurotoxicity, } \\
3(12 \%)\end{array}$ & Completed & $\begin{array}{l}\text { ClinicalTrials.gov identifier: } \\
\text { NCT02546167 }\end{array}$ \\
\hline $\begin{array}{l}\text { Idecabtagene } \\
\text { vicleucel (bb2121, } \\
\text { KarMMa) }\end{array}$ & 1 & 33 & 7 & Second & 4-1BB & $\begin{array}{l}50,150,450, \text { or } 800 \times \\
10^{6} \mathrm{CAR}^{+} \text {cells }\end{array}$ & $\begin{array}{l}3 \text { doses of } 300 \mathrm{mg} / \mathrm{m}^{2} \mathrm{Cy} \\
\text { and of } 30 \mathrm{mg} / \mathrm{m}^{2} \\
\text { fludarabine }\end{array}$ & $\begin{array}{l}\text { ORR, } 85 \% \\
15 \text { in CR (45\%) } \\
\text { mPFS, } 11.8 \text { months }\end{array}$ & $\begin{array}{l}\text { Grade } \geq 3 \text { CRS, } 2(6 \%) \\
\text { Grade } \geq 3 \text { neurotoxicity }, \\
1(3 \%)\end{array}$ & Completed & $\begin{array}{l}\text { ClinicalTrials.gov identifier: } \\
\text { NCT02658929 }\end{array}$ \\
\hline bb21217 & 1 & 8 & 9 & Second & $4-1 B B$ & $\begin{array}{l}150,450,800, \text { or } \\
1,200 \times 10^{6} \mathrm{CAR}^{+} \\
\text {cells }\end{array}$ & $\begin{array}{l}3 \text { doses of } 300 \mathrm{mg} / \mathrm{m}^{2} \mathrm{Cy} \\
\text { and of } 30 \mathrm{mg} / \mathrm{m}^{2} \\
\text { fludarabine }\end{array}$ & $\begin{array}{l}\text { ORR, } 86 \% \\
6 \text { achieving PR or better, including } \\
1 \mathrm{sCR}\end{array}$ & $\begin{array}{l}\text { Grade } \geq 3 \text { CRS, } 1 \text { ( } 12.5 \%) \\
\text { Grade } \geq 3 \text { neurotoxicity, } \\
1(12.5 \%)\end{array}$ & Ongoing & $\begin{array}{l}\text { ClinicalTrials.gov identifier: } \\
\text { NCT03274219 }\end{array}$ \\
\hline MCARH171 & 1 & 11 & 6 & Second & $4-1 \mathrm{BB}$ & $\begin{array}{l}\text { C1: } 1-5 \times 10^{8} \text { CAR }^{+} \\
\text {cells alone } \\
\text { C2: } 1-5 \times 10^{7} \text { CAR- } \\
\text { Ts }+ \text { LD } \\
\text { C3: } 1-5 \times 10^{8} \text { CAR- } \\
\text { Ts }+ \text { LD } \\
\text { C4: } 1-5 \times 10^{8} \text { CAR- }- \\
\text { Ts }+ \text { LD } 72-818 \times \\
10^{6} \mathrm{CAR}^{+} \text {cells } \\
\end{array}$ & $\begin{array}{l}1 \text { dose of } 3 \mathrm{~g} / \mathrm{m}^{2} \mathrm{Cy} \text { or } \\
3 \text { doses of } 300 \mathrm{mg} / \mathrm{m}^{2} \\
\text { Cy and of } 30 \mathrm{mg} / \mathrm{m}^{2} \\
\text { fludarabine }\end{array}$ & ORR, 64\% mDOR, 106 days & $\begin{array}{l}\text { Grade } \geq 3 \text { CRS, } 2 \text { (20\%) } \\
\text { Grade } \geq 3 \text { neurotoxicity, } \\
0\end{array}$ & Ongoing & $\begin{array}{l}\text { ClinicalTrials.gov identifier: } \\
\text { NCT03070327 }\end{array}$ \\
\hline FCAR143 & 1 & 7 & 11 & Second & $4-1 B B$ & $5 \times 10^{7}$ CAR-Ts & $\begin{array}{l}3 \text { doses of } \mathrm{Cy} \text { and } \\
\text { fludarabine }\end{array}$ & $\begin{array}{l}\text { ORR (at } 28 \text { days), } 100 \% \\
1 \text { relapse at day } 60 \text { with } \\
\text { BCMA-negative disease }\end{array}$ & $\begin{array}{l}\text { Grade } \geq 3 \text { CRS, } 0 \\
\text { Grade } \geq 3 \text { neurotoxicity, } \\
0\end{array}$ & Ongoing & $\begin{array}{l}\text { ClinicalTrials.gov identifier: } \\
\text { NCT03338972 }\end{array}$ \\
\hline Ст053 & 1 & 16 & 4 & Second & $4-1 B B$ & $\begin{array}{l}0.5,1.5, \text { or } 1.8 \times 10^{8} \\
\text { cells }\end{array}$ & $\begin{array}{l}3 \text { doses of } 300-500 \mathrm{mg} / \\
\mathrm{m}^{2} \text { Cy and } 20-25 \mathrm{mg} / \\
\mathrm{m}^{2} \text { fludarabine }\end{array}$ & $\begin{array}{l}\text { ORR, 100\% (13 of 13) } \\
3 \text { in CR } \\
6 \text { in VGPR } \\
4 \text { in PR }\end{array}$ & $\begin{array}{l}\text { Grade } \geq 3 \text { CRS, } 1 \\
\text { Grade } \geq 3 \text { neurotoxicity, } \\
0\end{array}$ & Ongoing & $\begin{array}{l}\text { ClinicalTrials.gov identifier: } \\
\text { NCT03915184 }\end{array}$ \\
\hline CT103A & 1 & 16 & $\begin{array}{l}N A(\geq 3 \text { prior } \\
\text { lines) }\end{array}$ & Second & $4-1 B B$ & $\begin{array}{l}1,3,6 \text {, or } 8 \times 10^{6} \\
\text { CAR-Ts } / \mathrm{kg}\end{array}$ & Cy and fludarabine & $\begin{array}{l}\text { ORR, } 100 \% \text {, with } 75 \% \text { in CR/sCR, } \\
\text { and } 25 \% \text { in VGPR. }\end{array}$ & $\begin{array}{l}\text { CRS/CRES, } 5 \text { grade 3, } 1 \\
\text { grade 4, } 1 \text { DLT (highest } \\
\text { dose) }\end{array}$ & Ongoing & ChiCTR-1800018137 \\
\hline BRD015 & I & 28 & 7 & Second & CD28 & $\begin{array}{l}5.4-25.0 \times 10^{6} \text { CAR- } \\
\text { Ts/kg }\end{array}$ & Cy and fludarabine & $\begin{array}{l}\text { ORR, } 87 \% \text { (BCMA strong expression } \\
\text { group) and 100\% (BCMA weak } \\
\text { expression group) }\end{array}$ & $\begin{array}{l}\text { Grade } \geq 3 \text { CRS, } 4 \text { ( } 14 \%) \\
\text { Grade } \geq 3 \text { neurotoxicity, } \\
0\end{array}$ & Ongoing & ChicTR-OPC-16009113 \\
\hline ALLO-715a & 1 & 90 & $\geq 3$ & Second & 4-1BB & $\begin{array}{l}40,120, \text { or } 320 \times 10^{6} \\
\text { CAR-Ts }\end{array}$ & $\begin{array}{l}3 \text { doses of } 300 \mathrm{mg} / \mathrm{m}^{2} \mathrm{Cy} \\
\text { and of } 30 \mathrm{mg} / \mathrm{m}^{2} \\
\text { fludarabine }\end{array}$ & Ongoing & Ongoing & Ongoing & $\begin{array}{l}\text { ClinicalTrials.gov identifier: } \\
\text { NCT04093596 }\end{array}$ \\
\hline $\begin{array}{l}\text { BCMA nano-antibody } \\
\text { CAR-T }\end{array}$ & I & $\begin{array}{l}7 \text { of } 15 \\
\text { planned }\end{array}$ & 10 & Second & 4-1BB & $\begin{array}{l}5,10, \text { or } 15 \times 10^{6} \\
\text { CAR-Ts/kg }\end{array}$ & Cy and fludarabine & $\begin{array}{l}\text { ORR, } 100 \% \text { (7 of 7) } \\
42.8 \% \text { in CR/sCR } \\
14.3 \% \text { in VGPR } \\
42.8 \% \text { in PR }\end{array}$ & $\begin{array}{l}\text { Grade } \geq 3 \text { CRS, } 2 \text { of } 7 \\
\text { Grade } \geq 3 \text { neurotoxicity, } \\
0\end{array}$ & Ongoing & $\begin{array}{l}\text { ClinicalTrials.gov identifier: } \\
\text { NCT03661554 }\end{array}$ \\
\hline
\end{tabular}

Abbreviations: BCMA, B-cell maturation antigen; CAR, chimeric antigen receptor; CAR-T, chimeric antigen receptor T cell; C, cycle; ChiCTR, Chinese Clinical Trials Repository; CR, complete response;

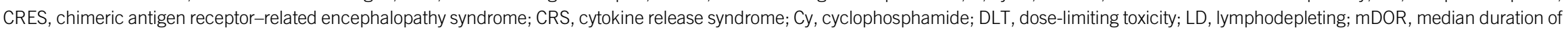

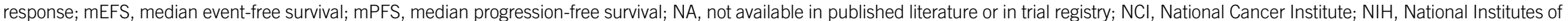
Health; ORR, objective response rate; PR, partial response; SCR, stringent complete response; UPenn, University of Pennsylvania; VGPR; very good partial response.

${ }^{a}$ Allogeneic off-the-shelf CAR product. 
TABLE A2. Non-BCMA CAR-T Clinical Trials for Multiple Myeloma

\begin{tabular}{|c|c|c|c|c|c|c|c|c|c|c|c|}
\hline Target and Trial & Phase & $\begin{array}{l}\text { No. of } \\
\text { Patients }\end{array}$ & $\begin{array}{l}\text { Median Lines } \\
\text { of Prior } \\
\text { Therapy }\end{array}$ & $\begin{array}{c}\text { CAR } \\
\text { Generation }\end{array}$ & Costimulatory Domain & Cell Dose & LD Regimen & Best Response & $\begin{array}{c}\text { Toxicity (grade } \geq 3 \\
\text { CRS/ } \\
\text { neurotoxicity) }\end{array}$ & Status & Study \\
\hline \multicolumn{12}{|l|}{ CD38 } \\
\hline $\begin{array}{l}\text { CAR2 Anti- } \\
\text { CD38 A2 }\end{array}$ & 1 & 72 & $\geq 2$ & NA & NA & NA & NA & Ongoing & Ongoing & Ongoing & $\begin{array}{l}\text { ClinicalTrials.gov } \\
\text { identifier: } \\
\text { NCT03464916 }\end{array}$ \\
\hline \multicolumn{12}{|l|}{ CD138 } \\
\hline ATLCAR.CD138 & I & 33 & $\geq 2$ & Second & CD28 & $\begin{array}{l}5,10,25,50,100 \\
\text { or } 200 \times 10^{6} \\
\text { CAR-Ts } / \mathrm{kg}\end{array}$ & $\begin{array}{l}3 \text { doses of } 300 \mathrm{mg} / \mathrm{m}^{2} \mathrm{Cy} \\
\text { and of } 30 \mathrm{mg} / \mathrm{m}^{2} \\
\text { fludarabine }\end{array}$ & Ongoing & Ongoing & Ongoing & $\begin{array}{l}\text { ClinicalTrials.gov } \\
\text { identifier: } \\
\text { NCT03672318 }\end{array}$ \\
\hline \multicolumn{12}{|l|}{$\begin{array}{l}\text { CD38/CD138/BCMA/ } \\
\text { SLAMF7/integrin } \\
\beta 7\end{array}$} \\
\hline Multitargeted CARs & 1 & 30 & $\geq 2$ & Fourth & $\begin{array}{l}\text { Unknown costimulatory } \\
\text { domain (simultaneously } \\
\text { expressing IL-7 and CCL19) }\end{array}$ & $\begin{array}{l}10^{6}-10^{7} \\
\text { CAR-Ts/kg }\end{array}$ & NA & Ongoing & Ongoing & Ongoing & $\begin{array}{l}\text { ClinicalTrials.gov } \\
\text { identifier: } \\
\text { NCT03778346 }\end{array}$ \\
\hline \multicolumn{12}{|l|}{ SLAMF7/CS1 } \\
\hline CS1-CAR T & I & 30 & $\geq 3$ & Second & $4-1 \mathrm{BB}$ & Dose escalation & Cy and fludarabine & Ongoing & Ongoing & Ongoing & $\begin{array}{l}\text { ClinicalTrials.gov } \\
\text { identifier: } \\
\text { NCT03710421 }\end{array}$ \\
\hline Anti-SLAMF7 & 1 & 42 & $\geq 3$ & NA & NA & $\begin{array}{l}0.3 \times 10^{6} \text { to } 12.0 \\
\times 10^{6} \mathrm{CAR}- \\
\mathrm{Ts} / \mathrm{kg}\end{array}$ & $\begin{array}{l}3 \text { doses of } 300 \mathrm{mg} / \mathrm{m}^{2} \mathrm{Cy} \\
\text { and of } 30 \mathrm{mg} / \mathrm{m}^{2} \\
\text { fludarabine }\end{array}$ & Ongoing & Ongoing & Ongoing & $\begin{array}{l}\text { ClinicalTrials.gov } \\
\text { identifier: } \\
\text { NCT03958656 }\end{array}$ \\
\hline $\begin{array}{l}\text { MELANI-01 } \\
\quad(\text { UCARTCS1A })^{a}\end{array}$ & 1 & 18 & $\geq 1$ & NA & NA & NA & NA & Ongoing & Ongoing & Ongoing & $\begin{array}{l}\text { ClinicalTrials.gov } \\
\text { identifier: } \\
\text { NCT04142619 }\end{array}$ \\
\hline \multicolumn{12}{|l|}{ NKG2D } \\
\hline CM-CS1 & 1 & 12 & 1 & First & $\begin{array}{l}\text { (NKG2D contains an } \\
\text { endogenously expressed } \\
\text { costimulatory domain, } \\
\text { Dap10) }\end{array}$ & $\begin{array}{l}1 \times 10^{6} \text { to } 3 \times 10^{7} \\
\text { total viable } \\
\text { T cells }\end{array}$ & None & $\begin{array}{l}\text { Objective clinical responses } \\
\text { to NKG2D-CAR-T therapy } \\
\text { alone not seen }\end{array}$ & $\begin{array}{l}\text { Grade } \geq 3 \text { CRS, } 0 \\
\text { Grade } \geq 3 \\
\text { neurotoxicity, } 0\end{array}$ & Completed & $\begin{array}{l}\text { ClinicalTrials.gov } \\
\text { identifier: } \\
\text { NCT02203825 }\end{array}$ \\
\hline \multicolumn{12}{|l|}{$\begin{array}{l}\text { CD56/CD38/ } \\
\text { CD138/BCMA }\end{array}$} \\
\hline Multitargeted CARs & 1 & 50 & NA & NA & NA & $10^{6}-10^{7}$ CAR-T/kg & NA & Ongoing & Ongoing & Ongoing & $\begin{array}{l}\text { ClinicalTrials.gov } \\
\text { identifier: } \\
\text { NCT03473496 } \\
\end{array}$ \\
\hline \multicolumn{12}{|l|}{$\kappa$-Light chain } \\
\hline CHARKALL & 1 & 7 & $\geq 1$ & Second & CD28 & $\begin{array}{l}\text { 2, } 10, \text { of } 20 \times 10^{7} \\
\text { к.CAR-T/m } / \mathrm{m}^{2}\end{array}$ & $\begin{array}{l}3 \text { doses of } 500 \mathrm{mg} / \mathrm{m}^{2} \mathrm{Cy} \\
\text { and of } 30 \mathrm{mg} / \mathrm{m}^{2} \\
\text { fludarabine }\end{array}$ & $\begin{array}{l}4 \text { of } 7 \text { with SD for } \\
2-17 \text { months }\end{array}$ & $\begin{array}{l}\text { Grade } \geq 3 \text { CRS, } 0 \\
\text { Grade } \geq 3 \\
\text { neurotoxicity, } 0\end{array}$ & Ongoing & $\begin{array}{l}\text { ClinicalTrials.gov } \\
\text { identifier: } \\
\text { NCT00881920 }\end{array}$ \\
\hline ATLCAR.к.28 & I & 20 & $\geq 2$ & Second & CD28 & $\begin{array}{l}5,10, \text { or } 20 \times 10^{5} \\
\text { cells/kg }\end{array}$ & $\begin{array}{l}3 \text { doses of } 70 \mathrm{mg} / \mathrm{m}^{2} \\
\text { bendamustine and of } \\
30 \mathrm{mg} / \mathrm{m}^{2} \text { fludarabine }\end{array}$ & Ongoing & Ongoing & Ongoing & $\begin{array}{l}\text { ClinicalTrials.gov } \\
\text { identifier: } \\
\text { NCT04223765 }\end{array}$ \\
\hline
\end{tabular}

Abbreviations: BCMA, B-cell maturation antigen; CAR, chimeric antigen receptor; CAR-T, chimeric antigen receptor T cells; CRS, cytokine release syndrome; Cy, cyclophosphamide; IL-7, interleukin 7;

LD, Iymphodepleting; NA, not available in published literature or in trial registry; SD, stable disease.

aAllogeneic off-the-shelf CAR-T product with endogenous T-cell receptor and SLAMF7 disrupted. 
TABLE A3. CD30 CAR-T Clinical Trials for $\mathrm{HL}$ and CD30+ $\mathrm{NHL}$

\begin{tabular}{|c|c|c|c|c|c|c|c|c|c|c|c|}
\hline Trial Site & Phase & Disease & $\begin{array}{c}\text { No. of } \\
\text { Patients }\end{array}$ & $\begin{array}{c}\text { Median Lines } \\
\text { of Prior } \\
\text { Therapy }\end{array}$ & $\begin{array}{c}\text { CAR } \\
\text { Generation }\end{array}$ & $\begin{array}{l}\text { Costimulatory } \\
\text { Domain }\end{array}$ & Cell Dose & LD Regimen & $\begin{array}{c}\text { Best } \\
\text { Response }\end{array}$ & $\begin{array}{c}\text { Toxicity } \\
\text { (grade } \geq 3 \text { CRS/ } \\
\text { neurotoxicity) }\end{array}$ & Study \\
\hline RELY30 & I & $\mathrm{HL} / \mathrm{NHL}$ & 66 & $r / r$ & Second & CD28 & $\begin{array}{l}2,10,20 \times 10^{7} \text { cells } / \\
m^{2}\end{array}$ & $\begin{array}{l}\text { Cy and } \\
\text { fludarabine }\end{array}$ & $\begin{array}{l}\text { Ongoing } \\
6 \text { in } \mathrm{CR} \\
\text { lasting up } \\
\text { to }>9 \\
\text { months } \\
3 \text { with PD }\end{array}$ & $\begin{array}{l}\text { Ongoing, no grade } 3 / \\
4 \text { events reported } \\
\text { to date }\end{array}$ & $\begin{array}{l}\text { ClinicalTrials.gov } \\
\text { identifier: } \\
\text { NCT02917083 }\end{array}$ \\
\hline $\begin{array}{l}\text { Immune Cell/ } \\
\text { Weifang } \\
\text { People's } \\
\text { Hospital }\end{array}$ & 1 & $\mathrm{HL} / \mathrm{ALCL}$ & 20 & $r / r$ & NA & NA & NA (dose escalation) & NA & Ongoing & Ongoing & $\begin{array}{l}\text { ClinicalTrials.gov } \\
\text { identifier: } \\
\text { NCT03383965 }\end{array}$ \\
\hline $\mathrm{NCl}$ & 1 & $\begin{array}{l}\mathrm{HL} / \mathrm{NHL} \\
\mathrm{ALCL}\end{array}$ & 79 & $\geq 2$ & NA & NA & $0.3-18 \times 10^{6} \mathrm{cell} / \mathrm{sg}$ & $\begin{array}{l}\text { Cy and } \\
\text { fludarabine }\end{array}$ & Ongoing & Ongoing & $\begin{array}{l}\text { ClinicalTrials.gov } \\
\text { identifier: } \\
\text { NCT03049449 }\end{array}$ \\
\hline$U_{N}{ }^{a}$ & 1 & $\begin{array}{l}\text { HL/cutaneous } \\
\text { T-cell } \\
\text { lymphoma }\end{array}$ & 59 & $\geq 2$ & Second & CD28 & $\begin{array}{l}2,5,10 \times 10^{7} \text { cells } / \\
\mathrm{m}^{2}\end{array}$ & $\begin{array}{r}\text { Fludarabine and } \\
\text { bendamustine }\end{array}$ & Ongoing & Ongoing & $\begin{array}{l}\text { ClinicalTrials.gov } \\
\text { identifier: } \\
\text { NCT03602157 }\end{array}$ \\
\hline $\begin{array}{l}\text { Wuhan Union } \\
\text { Hospital }\end{array}$ & I & $\begin{array}{l}\mathrm{HL} / \mathrm{NHL} / \\
\quad \mathrm{ALCL}\end{array}$ & 50 & $\geq 1^{\mathrm{b}}$ & Third & NA & NA & NA & Ongoing & Ongoing & $\begin{array}{l}\text { ClinicalTrials.gov } \\
\text { identifier: } \\
\text { NCT04008394 }\end{array}$ \\
\hline$U_{N C^{c}}$ & 1 & $\mathrm{HL} / \mathrm{NHL}$ & 18 & $\begin{array}{r}\text { Recurrent } \\
\text { disease }\end{array}$ & Second & CD28 & $\begin{array}{l}2,10,20 \times 10^{7} \text { cells/ } \\
\mathrm{m}^{2} \text { (maximum } \\
\text { dose, } 50 \times 10^{7} \\
\text { cells) }\end{array}$ & None & Ongoing & Ongoing & $\begin{array}{l}\text { ClinicalTrials.gov } \\
\text { identifier: } \\
\text { NCT02663297 }\end{array}$ \\
\hline $\mathrm{BCM}^{\mathrm{d}}$ & I & HL/NHL & 18 & $r / r^{b}$ & Second & NA & $\begin{array}{l}2,5,10 \times 10^{7} \text { cells } / \\
\mathrm{m}^{2}\end{array}$ & None & Ongoing & Ongoing & $\begin{array}{l}\text { ClinicalTrials.gov } \\
\text { identifier: } \\
\text { NCT01192464 }\end{array}$ \\
\hline $\mathrm{BCM}$ & 1 & $\mathrm{HL} / \mathrm{NHL}$ & 9 & $r / r, \geq 3$ & Second & CD28 & $\begin{array}{l}0.2-2 \times 10^{8} \\
\text { CD30.CAR-Ts } / \mathrm{m}^{2}\end{array}$ & None & $\begin{array}{l}2 \text { in } C R \\
3 \text { with SD }\end{array}$ & $\begin{array}{l}\text { Grade } \geq 3 \text { CRS, } 0 \\
\text { Grade } \geq 3 \\
\text { neurotoxicity, } 0\end{array}$ & $\begin{array}{l}\text { ClinicalTrials.gov } \\
\text { identifier: } \\
\text { NCT01316146 }\end{array}$ \\
\hline
\end{tabular}

Abbreviations: ALCL, anaplastic large-cell lymphoma; BCM, Baylor College of Medicine; CAR, chimeric antigen receptor; CAR-T, chimeric antigen receptor T cell; CR, complete response; CRS, cytokine release syndrome; Cy, cyclophosphamide; HL, Hodgkin lymphoma; LD, lymphodepleting; NA, not available in published literature or in trial registry; NCl, National Cancer Institute; NHL, non-Hodgkin Iymphoma; r/r, relapsed/refractory; PD, progressive disease; SD, stable disease; UNC, University of North Carolina at Chapel Hill.

${ }^{a}$ Co-administration with CAR-T co-expressing CCR4

${ }^{\mathrm{b}}$ Also enrolling newly diagnosed patients not fit for other therapy.

${ }^{c}$ Administered as consolidation after autologous stem-cell transplantation.

${ }^{d}$ Epstein-Barr virus-specific T cells. 
TABLE A4. CAR-T Clinical Trials for T-Cell Malignancies

\begin{tabular}{|c|c|c|c|c|c|c|c|c|c|c|c|}
\hline Target and Trial & Phase & Disease & $\begin{array}{l}\text { No. of } \\
\text { Patients }\end{array}$ & $\begin{array}{l}\text { Median } \\
\text { Lines of } \\
\text { Prior } \\
\text { Therapy }\end{array}$ & $\begin{array}{c}\text { CAR } \\
\text { Generation }\end{array}$ & $\begin{array}{l}\text { Costimulatory } \\
\text { Domain }\end{array}$ & Cell Dose & LD Regimen & Best Response & $\begin{array}{c}\text { Toxicity (grade } \geq 3 \\
\text { CRS/ } \\
\text { neurotoxicity) }\end{array}$ & Study \\
\hline \multicolumn{12}{|l|}{ CD4 } \\
\hline $\begin{array}{l}\text { First Affiliated } \\
\text { Hospital with } \\
\text { Nanjing Medical }\end{array}$ & I & $\begin{array}{l}\text { CD4 }{ }^{+} \text {T-cell } \\
\text { lymphoma }\end{array}$ & 34 & $r / r, \geq 1$ & NA & NA & NA & NA & Ongoing & Ongoing & $\begin{array}{l}\text { ClinicalTrials.gov } \\
\text { identifier: } \\
\text { NCT04219319 }\end{array}$ \\
\hline $\begin{array}{r}\text { Stony Brook } \\
\text { University }\end{array}$ & 1 & $\begin{array}{l}\text { CD4 }{ }^{+} \text {T-cell } \\
\text { leukemia/ } \\
\text { lymphoma }\end{array}$ & 20 & $r / r$ & Third & CD28, 4-1BB & $\begin{array}{l}\text { Up to } 4 \times \\
10^{6} \\
\text { T cells/kg }\end{array}$ & None & Ongoing & Ongoing & $\begin{array}{l}\text { ClinicalTrials.gov } \\
\text { identifier: } \\
\text { NCT03829540 }\end{array}$ \\
\hline \multicolumn{12}{|l|}{ CD5 } \\
\hline $\mathrm{BCM}$ & I & $\begin{array}{l}\mathrm{CD5}^{+} \text {T-cell } \\
\text { leukemia/ } \\
\text { lymphoma }\end{array}$ & 21 & $r / r,>5$ & Second & CD28 & $\begin{array}{l}1,5,10 \times \\
10^{7} \text { cells/ } \\
\mathrm{m}^{2}\end{array}$ & $\begin{array}{l}3 \text { doses of fludarabine } \\
30 \mathrm{mg} / \mathrm{m}^{2} \text { and } 3 \\
\text { doses of Cy } 500 \mathrm{mg} / \\
\mathrm{m}^{2} / \mathrm{d}\end{array}$ & $\begin{array}{l}\text { Ongoing, } 4 \text { of } 9 \\
\text { evaluable patients } \\
\text { obtained an } \\
\text { objective response, } \\
\text { with } 3 \text { achieving } \\
\text { a CR }\end{array}$ & $\begin{array}{l}\text { Ongoing No grade } \\
\text { 3/4 CRS or } \\
\text { neurotoxicity } \\
\text { reported to date }\end{array}$ & $\begin{array}{l}\text { ClinicalTrials.gov } \\
\text { identifier: } \\
\text { NCT03081910 }\end{array}$ \\
\hline \multicolumn{12}{|l|}{ CD7 } \\
\hline $\begin{array}{l}\text { PersonGen } \\
\text { BioTherapeutics } \\
\text { (Suzhou) }\end{array}$ & 1 & $\begin{array}{l}\text { CD7+ NK- or } \\
\text { T-cell } \\
\text { leukemia/ } \\
\text { lymphoma }\end{array}$ & 10 & $r / r$ & NA & NA & $\begin{array}{l}0.5-5 \times 10^{6} \\
\text { cells } / \mathrm{kg}\end{array}$ & $\begin{array}{l}\text { Cy or fludarabine and } \\
\mathrm{Cy}\end{array}$ & $\begin{array}{l}\text { Ongoing } \\
2 \text { of } 3 \text { patients with } \\
\text { MRD-negative CR }\end{array}$ & $\begin{array}{l}\text { Ongoing } \\
\text { Grade } \geq 3 \text { CRS, } \\
1 \text { of } 3 \text { patients } \\
\text { Grade } \geq 3 \\
\text { neurotoxicity, } 0\end{array}$ & $\begin{array}{l}\text { ClinicalTrials.gov } \\
\text { identifier: } \\
\text { NCT04004637 }\end{array}$ \\
\hline $\mathrm{BCM}$ & I & $\begin{array}{l}\mathrm{CD7}^{+} \mathrm{NK} \text { - or } \\
\text { T-cell } \\
\text { leukemia/ } \\
\text { lymphoma }\end{array}$ & 21 & $r / r$ & Second & CD28 & $\begin{array}{l}1,3,10 \times \\
10^{7} \text { cells/ } \\
\mathrm{m}^{2}\end{array}$ & $\begin{array}{l}3 \text { doses of fludarabine } \\
30 \mathrm{mg} / \mathrm{m}^{2} \text { and } 3 \\
\text { doses of Cy } 500 \mathrm{mg} / \\
\mathrm{m}^{2} / \mathrm{d}\end{array}$ & Ongoing & Ongoing & $\begin{array}{l}\text { ClinicalTrials.gov } \\
\text { identifier: } \\
\text { NCT03690011 }\end{array}$ \\
\hline $\begin{array}{l}\text { Xinqiao Hospital of } \\
\text { Chongqing }\end{array}$ & 1 & $\begin{array}{l}\text { CD7+ NK- or } \\
\text { T-cell } \\
\text { leukemia/ } \\
\text { lymphoma }\end{array}$ & 30 & $r / r$ & NA & NA & $\begin{array}{l}1,3,5 \times \\
10^{7} \text { cells/ } \\
\mathrm{m}^{2}\end{array}$ & $\begin{array}{l}6 \text { doses of fludarabine } \\
30 \mathrm{mg} / \mathrm{m}^{2} \text { and } 2-6 \\
\text { doses of Cy } 300 \mathrm{mg} / \\
\mathrm{m}^{2} / \mathrm{d} \text { and } 50-70 \mathrm{mg} / \\
\mathrm{m}^{2} \text { melphalan } \\
\text { (optional on the } \\
\text { basis of tumor } \\
\text { burden) }\end{array}$ & $\begin{array}{l}\text { Ongoing } \\
4 \text { of } 5 \text { patients with } \\
\text { MRD-negative CR, } \\
1 \text { of } 5 \text { patients with } \\
\text { MRD-positive CR } \\
\text { with quick relapse }\end{array}$ & $\begin{array}{l}\text { Ongoing } \\
\text { Grade } \geq 3 \text { CRS, } \\
5 \text { of } 5 \text { patients } \\
\text { Grade } \geq 3 \\
\text { neurotoxicity, } 0\end{array}$ & $\begin{array}{l}\text { ClinicalTrials.gov } \\
\text { identifier: } \\
\text { NCT04264078 }\end{array}$ \\
\hline
\end{tabular}

Abbreviations: BCM, Baylor College of Medicine; CAR, chimeric antigen receptor; CAR-T, chimeric antigen receptor T cell; CR, complete response; CRS, cytokine release syndrome; Cy, 
TABLE A5. CAR-T Clinical Trials for AML

\begin{tabular}{|c|c|c|c|c|c|c|c|c|c|c|c|}
\hline Target and Trial & Phase & Disease & $\begin{array}{l}\text { No. of } \\
\text { Patients }\end{array}$ & $\begin{array}{l}\text { Median Lines of } \\
\text { Prior Therapy }\end{array}$ & $\begin{array}{c}\text { CAR } \\
\text { Generation }\end{array}$ & $\begin{array}{l}\text { Costimulatory } \\
\text { Domain }\end{array}$ & Cell Dose & LD Regimen & Best Response & $\begin{array}{c}\text { Toxicity } \\
\text { (grade } \geq 3 \text { CRS/ } \\
\text { neurotoxicity) }\end{array}$ & Study \\
\hline \multicolumn{12}{|l|}{ CD123 } \\
\hline $\begin{array}{l}\text { Hebei Senlang } \\
\text { Biotechnology }\end{array}$ & 1 & $\begin{array}{c}\mathrm{CD}^{2} 23^{+} \\
\mathrm{AML}\end{array}$ & 15 & $r / r$ & NA & NA & NA & NA & Ongoing & Ongoing & $\begin{array}{l}\text { ClinicalTrials.gov } \\
\text { identifier: } \\
\text { NCT03796390 }\end{array}$ \\
\hline $\begin{array}{l}\text { Wuhan Union } \\
\text { Hospital, China }\end{array}$ & I & $\begin{array}{c}\mathrm{CD}^{2} 23^{+} \\
\mathrm{AML}\end{array}$ & 50 & $r / r, \geq 2$ & Third & $\begin{array}{c}\mathrm{CD} 28 \text { and } \\
4-1 \mathrm{BB}\end{array}$ & NA & NA & Ongoing & Ongoing & $\begin{array}{l}\text { ClinicalTrials.gov } \\
\text { identifier: } \\
\text { NCT04014881 }\end{array}$ \\
\hline Cellectis & I & AML & 59 & $r / r$ & NA & NA & NA & NA & Ongoing & Ongoing & $\begin{array}{l}\text { ClinicalTrials.gov } \\
\text { identifier: } \\
\text { NCT03190278 }\end{array}$ \\
\hline $\begin{array}{l}\text { City of Hope } \\
\text { Medical Center }\end{array}$ & 1 & $\begin{array}{l}\mathrm{CD} 123^{+} \\
\mathrm{AML}^{-} \\
\mathrm{ALL} / \\
\text { BPDCN }\end{array}$ & 42 & $r / r$ & Second & CD28 & $\begin{array}{l}50-200 \times 10^{6} \\
\text { CAR-Ts }\end{array}$ & Fludarabine and $\mathrm{Cy}$ & $\begin{array}{l}\text { Ongoing } \\
2 \text { of } 6 \text { in } \mathrm{CR}\end{array}$ & $\begin{array}{l}\text { Ongoing } \\
\text { No grade } 3 / 4 \\
\text { CRS/ } \\
\text { neurotoxicity } \\
\text { reported to date }\end{array}$ & $\begin{array}{l}\text { ClinicalTrials.gov } \\
\text { identifier: } \\
\text { NCT02159495 }\end{array}$ \\
\hline $\begin{array}{l}\text { St Jude Children's } \\
\text { Research } \\
\text { Hospital }\end{array}$ & I & $\begin{array}{c}\mathrm{CD} 123^{+} \\
\mathrm{AML}\end{array}$ & 32 & $r / r, \geq 2$ & NA & NA & $\begin{array}{l}\text { 3, } 10,30,100 \times \\
10^{5} \mathrm{CAR}-\mathrm{Ts} / \mathrm{kg} \\
\text { Maximum: } 2.5 \\
\times 10^{8} \mathrm{CAR}-\mathrm{Ts}\end{array}$ & Fludarabine and Cy & Ongoing & Ongoing & $\begin{array}{l}\text { ClinicalTrials.gov } \\
\text { identifier: } \\
\text { NCT04318678 }\end{array}$ \\
\hline UPenn & 1 & AML & 12 & $r / r$ & Second & $4-1 B B$ & $\begin{array}{c}1,2,5 \times 10^{6} \\
\text { CAR-Ts/kg }\end{array}$ & Fludarabine and $\mathrm{Cy}$ & Ongoing & Ongoing & $\begin{array}{l}\text { ClinicalTrials.gov } \\
\text { identifier: } \\
\text { NCT03766126 }\end{array}$ \\
\hline $\begin{array}{l}\text { Beijing } \\
\text { Immunochina } \\
\text { Medical } \\
\text { Science and } \\
\text { Technology }\end{array}$ & । & $\begin{array}{c}\mathrm{CD}^{2} 23^{+} \\
\mathrm{AML}^{+}\end{array}$ & 15 & $r / r$ & NA & NA & NA & Fludarabine and Cy & Ongoing & Ongoing & $\begin{array}{l}\text { ClinicalTrials.gov } \\
\text { identifier: } \\
\text { NCT03585517 }\end{array}$ \\
\hline $\begin{array}{l}\text { Affiliated Hospital } \\
\text { to Academy of } \\
\text { Military Medical } \\
\text { Sciences }^{a}\end{array}$ & I & $\begin{array}{c}\mathrm{CD} 123^{+} \\
\mathrm{AML}^{-}\end{array}$ & 20 & $\begin{array}{l}r / r \text {, } \\
\text { post-allogenic } \\
\text { HSCT }\end{array}$ & Second & $4-1 B B$ & NA & NA & Ongoing & Ongoing & $\begin{array}{l}\text { ClinicalTrials.gov } \\
\text { identifier: } \\
\text { NCT03114670 }\end{array}$ \\
\hline UPenn $^{\mathrm{b}}$ & 1 & AML & 7 & $4(2-6)$ & Second & $4-1 B B$ & $\begin{array}{l}\text { Planned 3-6 } \\
\text { doses of } 4 \times \\
10^{6} \text { CAR-Ts/kg }\end{array}$ & Cy $1 \mathrm{~g} / \mathrm{m}^{2}$ (optional) & $\begin{array}{c}\text { 0/5 responses } \\
\text { All patients } \\
\text { experienced } \\
\text { progression }\end{array}$ & $\begin{array}{l}\text { Grade } \geq 3 \text { CRS } \\
58 \% \\
\text { Grade } \geq 3 \\
\text { neurotoxicity, } 0\end{array}$ & $\begin{array}{l}\text { ClinicalTrials.gov } \\
\text { identifier: } \\
\text { NCT02623582 }\end{array}$ \\
\hline $\begin{array}{l}\text { Cellectis } \\
\text { (UCART123, } \\
\text { ABC123) }^{\mathrm{a}}\end{array}$ & 1 & BPDCN & 1 & $r / r$ & Second & $4-1 B B$ & $\begin{array}{l}6.25-62.5 \times 10^{5} \\
\text { CAR-Ts/kg }\end{array}$ & Fludarabine and $\mathrm{Cy}$ & Terminated & $\begin{array}{l}\text { Terminated after } \\
\text { grade } 5 \text { CRS in } \\
\text { first patient }\end{array}$ & $\begin{array}{l}\text { ClinicalTrials.gov } \\
\text { identifier: } \\
\text { NCT03203369 }\end{array}$ \\
\hline $\begin{array}{l}\text { Cellectis } \\
\text { (UCART123, } \\
\text { AMELI-01) }\end{array}$ & I & AML & 59 & $r / r$ & Second & $4-1 B B$ & $\begin{array}{c}\text { Dose reduced to } \\
6.25 \times 10^{4} \\
\text { CAR-Ts/kg }\end{array}$ & Fludarabine and Cy & Ongoing & Ongoing & $\begin{array}{l}\text { ClinicalTrials.gov } \\
\text { identifier: } \\
\text { NCT03190278 }\end{array}$ \\
\hline
\end{tabular}


TABLE A5. CAR-T Clinical Trials for AML (continued)

\begin{tabular}{|c|c|c|c|c|c|c|c|c|c|c|c|}
\hline Target and Trial & Phase & Disease & $\begin{array}{l}\text { No. of } \\
\text { Patients }\end{array}$ & $\begin{array}{l}\text { Median Lines of } \\
\text { Prior Therapy }\end{array}$ & $\begin{array}{c}\text { CAR } \\
\text { Generation }\end{array}$ & $\begin{array}{l}\text { Costimulatory } \\
\text { Domain }\end{array}$ & Cell Dose & LD Regimen & Best Response & $\begin{array}{c}\text { Toxicity } \\
\text { (grade } \geq 3 \text { CRS/ } \\
\text { neurotoxicity) }\end{array}$ & Study \\
\hline \multicolumn{12}{|l|}{ CLL/CD33 } \\
\hline $\begin{array}{l}\text { iCell Gene } \\
\text { Therapeutics }\end{array}$ & I & $\begin{array}{l}\text { AML/MDS/ } \\
\text { MPN }\end{array}$ & 20 & $r / r$ & NA & NA & NA & Fludarabine and Cy & $\begin{array}{l}\text { Ongoing } \\
2 \text { in } \mathrm{CR}\end{array}$ & Ongoing & $\begin{array}{l}\text { ClinicalTrials.gov } \\
\text { identifier: } \\
\text { NCT03795779 }\end{array}$ \\
\hline \multicolumn{12}{|l|}{ CLL1 } \\
\hline $\mathrm{BCM}$ & I & $\begin{array}{l}\mathrm{CLL1}^{+} \\
\mathrm{AML}\end{array}$ & 18 & $r / r$ & Second & $4-1 B B$ & $\begin{array}{c}1,3,10 \times 10^{7} \\
\text { CAR-Ts } / \mathrm{m}^{2}\end{array}$ & NA & Ongoing & Ongoing & $\begin{array}{l}\text { ClinicalTrials.gov } \\
\text { identifier: } \\
\text { NCT04219163 }\end{array}$ \\
\hline \multicolumn{12}{|l|}{ FLT3 } \\
\hline Amgen & I & $\begin{array}{r}\mathrm{FLT3}^{+} \\
\mathrm{AML}^{2}\end{array}$ & 40 & $r / r$ & NA & NA & NA & Fludarabine and Cy & Ongoing & Ongoing & $\begin{array}{l}\text { ClinicalTrials.gov } \\
\text { identifier: } \\
\text { NCT03904069 }\end{array}$ \\
\hline \multicolumn{12}{|l|}{ Lewis-Y } \\
\hline $\begin{array}{l}\text { Peter MacCallum } \\
\text { Cancer Center }\end{array}$ & I & $\begin{array}{c}\text { Lewis-Y }{ }^{+} \\
\text {AML }\end{array}$ & 5 & $r / r, \geq 1$ & Second & CD28 & $\begin{array}{c}5 \times 10^{8} \text { to } 1.3 \times \\
10^{9} \text { CAR-T }\end{array}$ & $\begin{array}{l}\text { Fludarabine } 30 \mathrm{mg} / \\
\mathrm{m}^{2} \text { days } 1-5 \text { and } \\
\text { cytarabine } 2 \mathrm{~g} / \\
\mathrm{m}^{2} \text { days } 1-5\end{array}$ & $\begin{array}{l}\text { Transient response in } \\
3 \text { of } 4 \text { patients, } \\
\text { including } 1 \\
\text { cytogenetic CR }\end{array}$ & $\begin{array}{l}\text { Grade } \geq 3 \text { CRS, } 0 \\
\text { Grade } \geq 3 \\
\text { neurotoxicity, } 0\end{array}$ & $\begin{array}{l}\text { ClinicalTrials.gov } \\
\text { identifier: } \\
\text { NCT01716364 }\end{array}$ \\
\hline
\end{tabular}

Abbreviations: ALL, acute lymphocytic leukemia; AML, acute myelogenous leukemia; BPDCN, blastic plasmacytoid dendritic cell neoplasma; CAR, chimeric antigen receptor; CAR-T, chimeric antigen

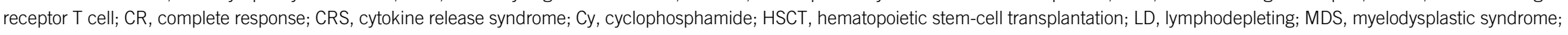
$\mathrm{NA}$, not available in published literature or in trial registry; $r / r$, relapsed or refractory.

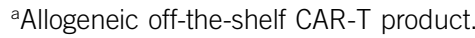

bBiodegradable T electroporated with anti-CD123 CAR mRNA. 